Revista Brasileira de Meteorologia, v.28, n.3, 231 - 245, 2013

\title{
ENERGETICS OF CYCLOGENESIS EVENTS OVER THE SOUTHERN COAST OF BRAZIL
}

\author{
MARCELO BARBIO ROSA, NELSON JESUZ FERREIRA, MANOEL ALONSO GAN, LÚCIA HELENA \\ RIBAS MACHADO
}

\author{
Instituto Nacional de Pesquisas Espaciais, Centro de Previsão de Tempo e Estudos Climáticos (INPE/ \\ CPTEC), São José dos Campos, SP, Brasil
}

marcelo.barbio@cptec.inpe.br, manoel.gan@cptec.inpe.br, lucia.ribas@cptec.inpe.br, nelson.ferreira@cptec. inpe.br

Received September 2012 - Accepted March 2013

\begin{abstract}
An analysis of 58 cyclogenesis cases occurred from 2003 to 2011 over the southern Brazilian coast is presented focusing on the energy cycle proposed. For this analysis the National Centers for Environmental Prediction (NCEP) data was utilized to create the composite fields of all selected days as also to that of transitional seasons (austral spring and autumn), when it was verified a high number of cyclones. In the analysis, a deepening of a pre-existing surface trough over Paraguay was observed two days (D-2) before the surface pressure had reached its minimum over the southern Brazilian coast. Typically, the cyclogenetic process begins on the southern Brazil coast and spreads in a NW-SE direction, strengthening along its path. On D-2 the jet stream is almost zonally oriented and then when the cyclone is completely formed (D0), this acquire a cyclonic curvature, with two cores: one strongest in the SE and the other one in the NW direction. As soon as the geopotential anomaly for short waves (Gh) is in phase with anomaly for long waves (Gl) on D-1, the PhKh term increases in magnitude, becoming the dominant one. During all evolution stages, the dominant terms were the baroclinic ( $\mathrm{PIPh}$ and $\mathrm{PhKh})$, followed by the barotropic $(\mathrm{KlKh})$ term. The friction term (RKh) had a secondary role and the source/sink of non conservative energy and flux of the available potential energy ( $\mathrm{RPh}$ ) did not contributed to the deepening of the surface low, which is not depending of the convective activity inside it. Significant differences were not observed in the mechanisms of cyclogenesis development and maintenance during the transition months, except for a greater availability of kinetic $(\mathrm{Kh})$ and potential $(\mathrm{Ph})$ energy and baroclinic and barotropic conversion terms during the austral autumn.
\end{abstract}

Keywords: energetic, cyclogenesis, baroclinic

RESUMO: ENERGÉTICA DE EVENTOS DE CICLOGÊNESES NA COSTA SUL DO BRASIL Neste estudo é feita uma análise de 58 casos de ciclogênese ocorridos entre 2003-2011 sobre a costa do sul do Brasil, focando o ciclo de energia. Nesta análise foram utilizados dados do National Centers for Environmental Prediction (NCEP) para criar os campos compostos dos dias selecionados e das estações de transição (primavera e outono austral), quando foi verificado um elevado número de ciclones. Observou-se um aprofundamento de um cavado pré-existente em superfície sobre o Paraguai, dois dias antes (D-2) da pressão na superfície atingir o seu mínimo sobre a costa da região sul do Brasil. Tipicamente, o processo de ciclogênese começa sobre esta região e se propaga para sudeste, intensificando ao longo de sua trajetória. Em D-2 a corrente de jato está quase zonalmente orientada, mas adquire uma curvatura ciclônica, com um núcleo no setor SE e o outro à NW quando o ciclone está completamente formado (D0). Quando a anomalia de geopotencial para ondas curtas (Gh) entra em fase com a anomalia para ondas longas (Gl), em D-1, ocorre o aumento de $\mathrm{P}_{\mathrm{h}} \mathrm{K}_{\mathrm{h}}$, que se torna dominante. Durante todas as fases de evolução, os termos mais importantes foram o baroclínico $\left(\mathrm{P}_{1} \mathrm{P}_{\mathrm{h}}\right.$ e $\left.\mathrm{P}_{\mathrm{h}} \mathrm{K}_{\mathrm{h}}\right)$, seguido pelo barotrópico $\left(\mathrm{K}_{1} \mathrm{~K}_{\mathrm{h}}\right)$. $\mathrm{O}$ termo de atrito $\left(\mathrm{RK}_{\mathrm{h}}\right)$ teve um papel secundário, e o termo de fonte/sumidouro de energia e fluxo de energia potencial disponível $\left(\mathrm{RP}_{\mathrm{h}}\right)$ não contribuiu para o aprofundamento de baixa superfície, mostrando que este último não 
depende da atividade convectiva local. Durante os meses de transição, não foram observadas diferenças significativas nos mecanismos de desenvolvimento ciclogenético e manutenção, exceto por haver uma maior disponibilidade de energia cinética $\left(\mathrm{K}_{\mathrm{h}}\right)$ e potencial $\left(\mathrm{P}_{\mathrm{h}}\right)$, e também por haver uma maior troca de energia por conversão baroclínica e barotrópica durante o outono austral. Palavras Chave: energética, ciclogênese, baroclínia.

\section{INTRODUCTION}

Cyclogenesis events over Brazil's southern coast frequently occur during the southern winter (Gan and Rao, 1991; Sinclair, 1995 and Reboita, 2006). This mechanism, especially when it generates a cyclone over the continent, is responsible for severe weather situations (Seluchi, 1995) and can be responsible for property damage and, in extreme cases, loss of lives. Therefore, improving the understanding of their evolution, development and the energy cycle will contribute to diagnose the behavior of this important weather phenomenon and also to establish preventive actions.

The mechanisms of formation, maintenance and dissipation of extratropical cyclones have being studied for decades. Since the pioneering work of Petterssen (1956) and Klein (1957), many studies have been conducted on the cyclogenetic features of extratropical cyclones in the Northern Hemisphere - e.g. Sanders and Gyakum (1980); Roebber (1984); Nielsen and Dolen (1992). However, those in the Southern Hemisphere extratropics have received less attention than their Northern Hemisphere counterparts - e.g. Gan and Rao (1994); Sinclair (1995); Mendes et al. (2007). In the last decades, cyclogenesis over South America (SA) and neighboring oceans has been the subject of increased interest due to the accessibility of satellite data and well as reanalysis products.

Gan and Rao (1991) made an extensive analysis of cyclogenesis over SA. In their research they found that there are two cyclogenetical regions, one above the Gulf of San Matias $\left(42.5^{0} \mathrm{~S} ; 62.5^{0} \mathrm{~W}\right)$ and another over Uruguay $\left(32.5^{0} \mathrm{~S} ; 55.0^{0}\right.$ W). They found a high frequency of events during the austral winter over Uruguay and over the Gulf of San Matias during the austral summer. Sinclair (1994), Hoskins and Hodges (2005) and Reboita (2006) observed a third cyclogenetical region over the southern coast of Brazil, around $25^{\circ} \mathrm{S}$.

Over the southern coast of Brazil the factors that may contribute to cyclogenesis is the presence of a trough at high tropospheric levels (Seluchi et al., 2001), the presence of a frontal system (Seluchi et al., 2001), the transport of moisture to the south/southeast coast of Brazil made by South Atlantic Subtropical High Pressure (Reboita, 2006) and from the Amazon (Ferreira, 1988), convergence generated by movement of the subtropical ridge (Seluchi, 1995, Seluchi et al., 2001). According to Piva et al. (2010) cyclogenesis events in southern
Brazil are preceded by the pre-existence of a $500 \mathrm{hPa}$ trough, continuous heat and moisture fluxes coming from equatorial SA and the impact of local sensible heat and latent heat fluxes. Also when the cyclone is formed it is maintained primarily by baroclinic conversion such that the ageostrophic geopotential flux convergence contributes to maintenance of the system. Sanders and Gyakum (1980) also found that fast and explosive deepening oceanic typically occurs when a mass of cold air displaces over oceanic areas with a strong temperature gradient arises due to the warm surface ocean current.

From the dynamical processes point of view, cyclogenesis over southern SA grows essentially by baroclinic conversion, although barotropic instability may also play a role (Gan and Rao, 1999). Upon reaching maturity, these systems begin to decay barotropically, with the kinetic energy of the cyclone being converted into kinetic energy of the basic state. Also they noted that during the growing phase, the disturbance grows by baroclinic conversion, although non-conservative energy sources and energy fluxes from the outside studied domain may also contribute.

Despite the increased number of studies on cyclogenesis over South America and vicinities, several components of the dynamic processes involved are not yet fully understood, as the magnitude of the baroclinic and barotropic exchange, as formulated by Lorenz (1955), and the interaction between long (slow) waves against short (fast) ones and how this contributes to growing and dissipation of this system over the south coast of Brazil. Aiming to contribute to understanding this problem the objective of this study is to analyze the main mechanisms of the genesis and evolution of extratropical cyclones over the southern Brazilian coast linked with their energy cycles, and never studied before

\section{DATA AND METHODOLOGY}

The data set used in this study consists of the global NCEP daily analyses of geopotential, horizontal wind components, vertical velocity and temperature at standard pressure levels from 1000 to $200 \mathrm{hPa}$, with a $1.0^{\circ} \times 1.0^{\circ}$ degree (T126L62) of horizontal resolution covering the 2003 to 2011 period.

The formularization for estimating the energy cycles was the same presented by Lau and Lau (1984) and adapted by Gan and Rao (1999): 


$$
\begin{aligned}
& P_{h}=g^{-1} \int \frac{T_{h}^{2}}{2 \sigma} d p \\
& K_{h}=g^{-1} \int \frac{u_{h}^{2}+v_{h}^{2}}{2} d p \\
& \frac{\partial K_{h}}{\partial t}=P_{h} K_{h}+K_{l} K_{h}+R K_{h} \\
& \frac{\partial P_{h}}{\partial t}=P_{l} P_{h}-P_{h} K_{h}+R P_{h} \\
& P_{l} P_{h}=-g^{-1} \int \sigma^{-1}\left(u_{h} T_{h} \frac{\partial T_{l}}{\partial x}+v_{h} T_{h} \frac{\partial T_{l}}{\partial y}\right) d p \\
& K_{l} K_{h}=-g^{-1} \int\left(u_{h} u_{h} \frac{\partial u_{l}}{\partial x}+u_{h} v_{h} \frac{\partial u_{l}}{\partial y}+\right. \\
& \left.v_{h} u_{h} \frac{\partial v_{l}}{\partial x}+v_{h} v_{h} \frac{\partial v_{l}}{\partial y}\right) d p \\
& P_{h} K_{h}=-g^{-1} \int \frac{R}{p} \omega_{h} T_{h} d p
\end{aligned}
$$

where $P_{h}$ and $K_{h}$ stand respectively for the available potential energy and the kinetic energy terms of short waves disturbances. The terms $\mathrm{P}_{1} \mathrm{P}_{\mathrm{h}}$ and $\mathrm{P}_{\mathrm{h}} \mathrm{K}_{\mathrm{h}}$ are the baroclinic conversion of the system, where the available potential energy of the low frequency $\left(\mathrm{P}_{1}\right)$ is converted to potential energy of the high frequency $\left(\mathrm{P}_{\mathrm{h}}\right)$ and subsequently to high frequency kinetic energy $\left(\mathrm{K}_{\mathrm{h}}\right)$. The $\mathrm{K}_{1} \mathrm{~K}_{\mathrm{h}}$ term represents the barotropic conversion, when it is positive the kinetic energy of the high frequency is converted into kinetic energy of low frequency $\left(\mathrm{K}_{1}\right)$. The terms $\mathrm{RP}_{\mathrm{h}}$ and $\mathrm{RK}_{\mathrm{h}}$ are residuals. The former is associated to the sources and sinks of non-conservatives energy (diabatic processes) and flux of the available potential energy, the latter is related to the kinetic energy fluxes of the perturbations of high frequency disturbances (Gan and Rao, 1999). The term $g$ means gravitational acceleration $\left(\mathrm{m} \mathrm{s}^{-2}\right), \mathrm{T}$ temperature $(\mathrm{K}), \mathrm{u}$ and $\mathrm{v}$ are, respectively, the zonal and meridional wind $\left(\mathrm{m} \mathrm{s}^{-1}\right)$ components, $\omega$ the vertical velocity $\left(\mathrm{hPa} \mathrm{s}^{-1}\right)$ and $\sigma$ the static stability parameter which is expressed by:

$$
\sigma=\left(\frac{T_{l}}{c_{p}}-\frac{p}{R} \frac{\partial T_{l}}{\partial p}\right)
$$

where $T_{1}$ represents the low frequency air temperature of the disturbances, $c_{p}$ the specific heat of the air, $R$ the ideal gas constant and $\mathrm{p}$ the pressure at a given level.

In the present study we used harmonic decomposition in Fourier series in space, considering long waves as those with wave numbers lower than 5 , similar to the formulation presented by Saltzman and Fleisher (1960). The long waves are represented by the subscript (l) resulting from adding up the first five modes plus the zonal mean. The others have been classified as short waves (h). The selection of cyclogenesis days was based on objective as well as visual criteria. In the former, the studied area was located over the southern coast of Brazil, delimited by latitude $45^{\circ} \mathrm{S}$ and $25^{\circ} \mathrm{S}$ and by longitude $50^{\circ} \mathrm{W}$ and $20^{\circ} \mathrm{W}$. Ciclogenetic activity was selected when the surface pressure inside at any grid point in the box was less than 1000 $\mathrm{hPa}$ and the relative vorticity was below $-1.5 \times 10^{-5} \mathrm{~s}^{-1}$. This last value was chosen following Sinclair (1994). Through a simple method (surface pressure $<1000 \mathrm{hPa}$ and $\zeta<-1.5 \times 10^{-5} \mathrm{~s}^{-1}$ ), 58 cyclones were identified during the April 1, 2003 to June 31, 2011 period. In the latter procedure (visual criterion), three cases were removed because they were trough or migratory cyclones with centers outside of the defined box and not formed in the select region. The selected cyclone days are shown in Table 1.

All terms of Equations 1 to 7 were calculated for the genesis day, as well for two days before (D-2) and for one day later $(\mathrm{D}+1)$ when the extratropical cyclone was already mature. Finally, all 58 calculated and observed values were time averaged, included the calculus of the root mean square deviation, and vertically integrated from 1000 to $200 \mathrm{hPa}$. The mean fields and anomalies were calculated over the 58 cases identified.

In this study an analysis to the spring (October, November and December) and autumn (April, May and June) seasons is also included to the season. There were a large number of the cyclogenesis cases, when compared to the other two seasons (winter and summer).

\section{RESULTS}

Figure 1 shows the composites fields for the four days studied (D-2 to D+1), for the following fields: mean sea level pressure and its respective square root deviation (contour field), direction and speed of the $1000 \mathrm{hPa}$ wind. In these fields we can observe a cyclonic circulation over the southeastern coast of the South America with a closed cyclonic circulation on D-1 with a NW to SE orientation. This close cyclonic circulation originates from a cutoff from the continental surface low - that is not the thermal low, known as Chaco Low, which was in phase with a migratory trough at middle levels (Figure 3b, D-1). Despite the square root deviation inside the surface low area was relatively high compared to the prevailing field around the low pressure system, especially on days when the cyclone already was becoming mature, the surface low was still evident when the square root deviation is added to the mean field. The jet stream (Figure 2) shows an anticyclonic curvature over the tropical region of South America during the four composite days, being 
Table 1 - Days, months and years of cyclones with centers around $350 \mathrm{~S}$ and $350 \mathrm{~W}$ during the April 1, 2003 to August 31,2011 period. Shaded cells indicate months not searched.

\begin{tabular}{|c|c|c|c|c|c|c|c|c|c|c|}
\hline & 2003 & 2004 & 2005 & 2006 & 2007 & 2008 & 2009 & 2010 & 2011 & Total \\
\hline January & & & & & & & 4 & & 13 & 2 \\
\hline February & & & & & & 03 & 24 & & 11 & 3 \\
\hline March & & & & 25 & & & 14 & & & 2 \\
\hline April & 07 e 12 & & & & 10 & & & 08 e 28 & & 5 \\
\hline May & 25 & 27 & & & 13 & 7 e 26 & 15 & & 27 & 7 \\
\hline June & 12 & & 26 & 01 e 28 & 16 & 11 & & 06 & 08 & 8 \\
\hline July & & & & & 16 e 26 & 23 & 21 & & & 4 \\
\hline August & 18 & & 25 & 10 & 21 & 3 & 21 & 15 & & 7 \\
\hline September & & & 03 & 03 & 25 & & & 15 & & 4 \\
\hline October & & & & & 14 e 18 & & & 20 & & 3 \\
\hline November & 04 e 14 & 13 & & & 15 & 01 & 24 & 03 & & 7 \\
\hline December & 09 & & 18 & 21 e 27 & & 04 & 14 & & & 6 \\
\hline Total & 8 & 2 & 4 & 7 & 10 & 8 & 8 & 7 & 4 & 58 \\
\hline
\end{tabular}
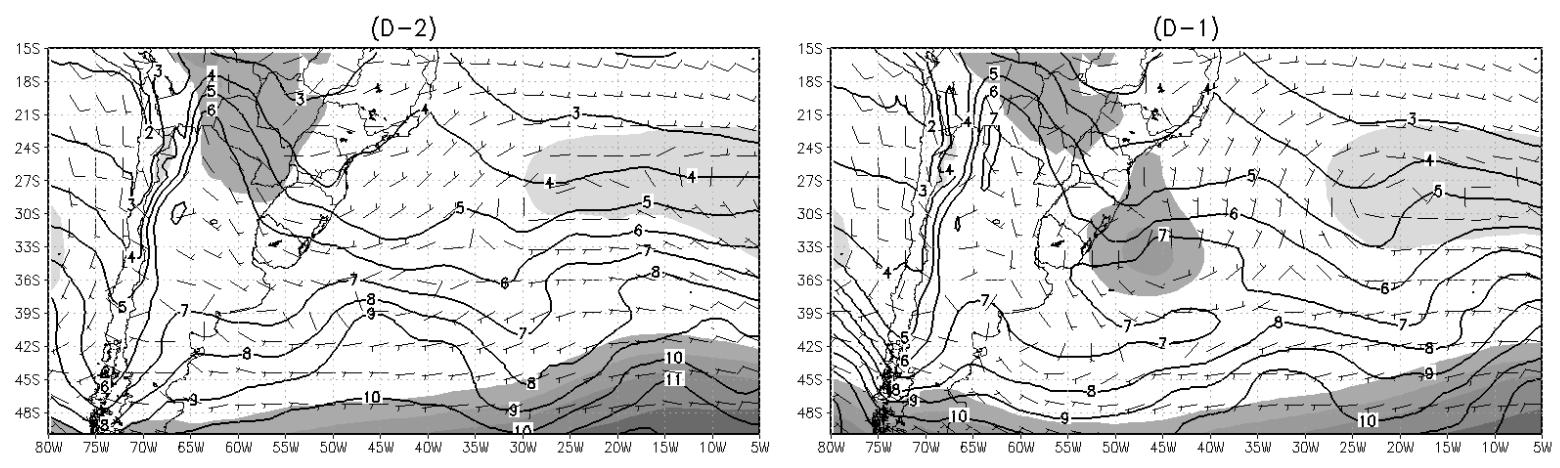

(a)
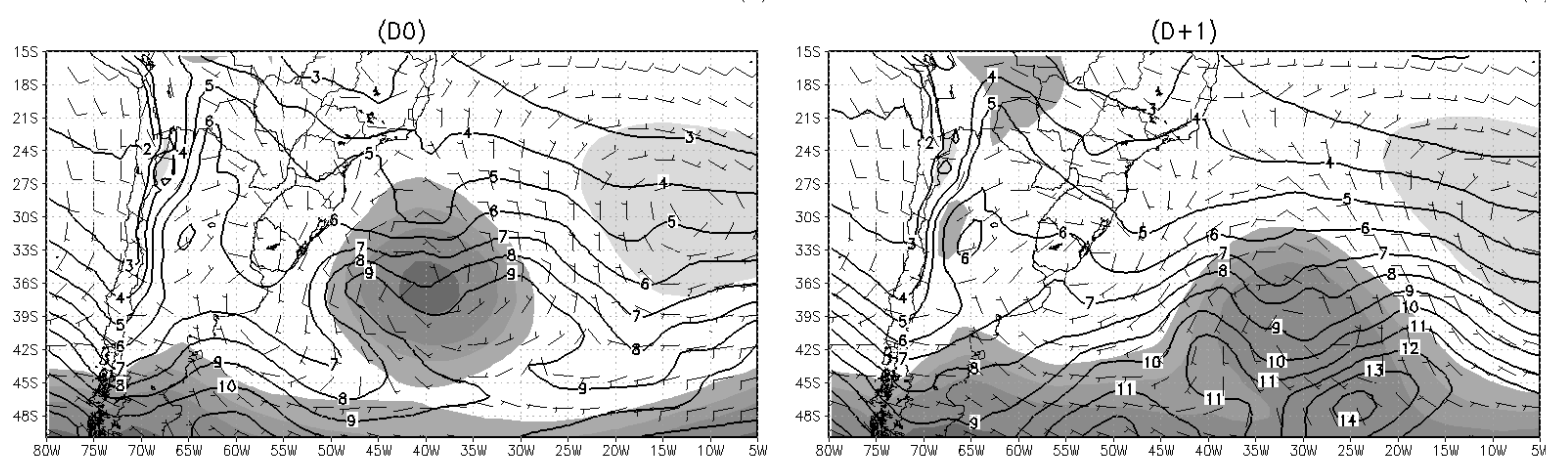

(c)

(d)

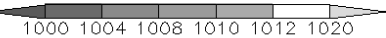

Figure 1 - Composite fields for the four days studied (D-2 to D+1), to the mean sea level pressure (shaded in hPa) and its respective square root deviation (contour), direction and speed of the $1000 \mathrm{hPa}$ wind (barb). (Units: pressure and deviation in $\mathrm{hPa}$ and wind in $\mathrm{ms}-1$ ). 

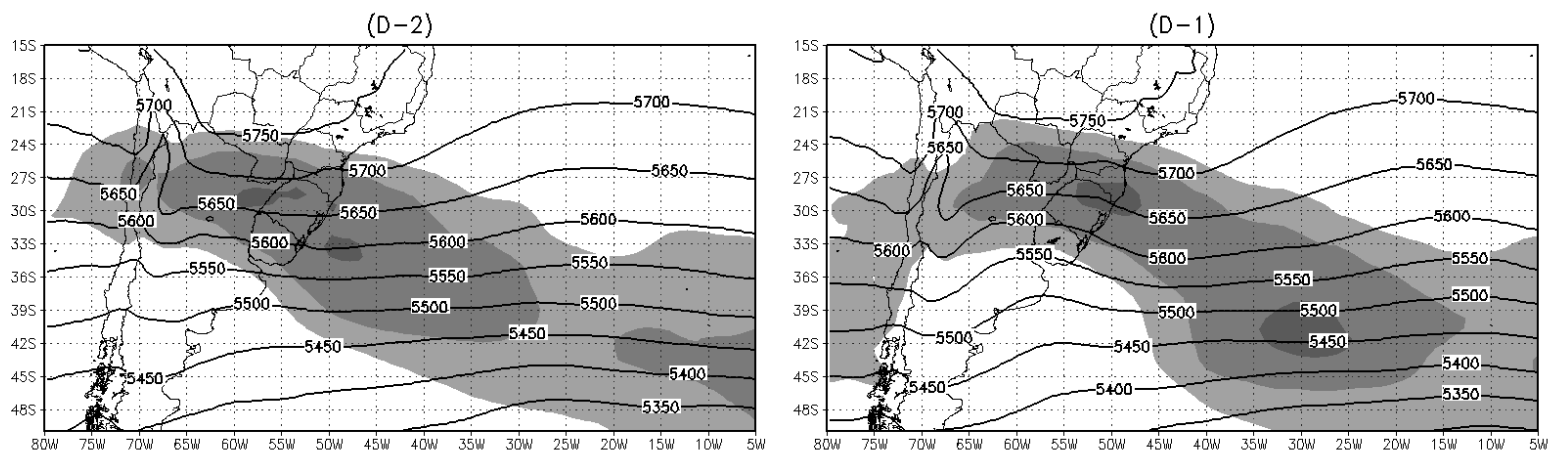

(a)
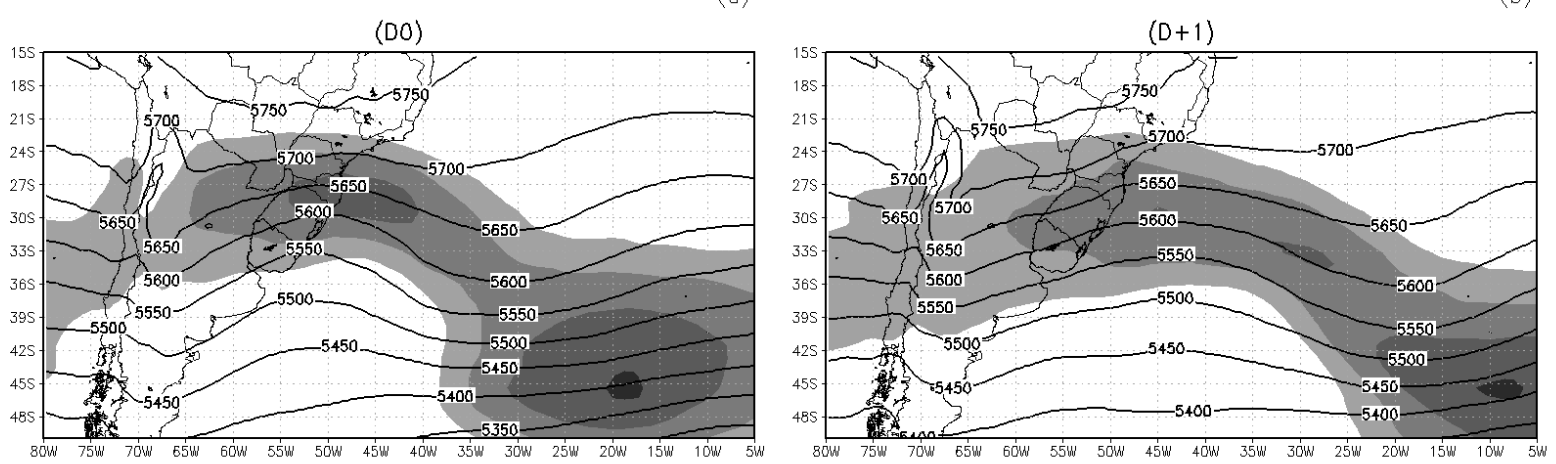

(b)

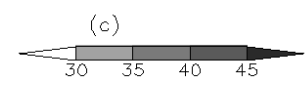

(d)

Figure 2 - Composite fields for the four days studied (D-2 to D+1), to the jet stream magnitude (shaded) at $200 \mathrm{hPa}$ and geopotential thickness between 1000 and $500 \mathrm{hPa}$ (contour). (Units: jet stream in $\mathrm{m} \mathrm{s}-1$ and geopotential in meters).

characterized by two speed cores and a diffluent flow over the eastern coast of Brazil. At the same time, the surface cyclone was deepening. In this situation there is a transport of momentum from short waves to long waves, as will be later shown for the barotropic conversion term case. Also, the strongest speed core, centered at $45^{\circ} \mathrm{S}$ and $20^{\circ} \mathrm{W}$ on Day 0 , tends to displace in a SE direction, transporting momentum to the polar jet.

Figure 3 shows the 500-hPa geopotential (left column) and temperature (right column) geopotential anomalies for the short waves $\left(G_{h}\right)$ and long waves $\left(G_{l}\right)$. During the four composite days, an eastward displacement $\left(\sim 9^{\circ}\right.$ lon/day of phase speed) of the geopotential short waves was observed, while the long waves showed a small phase velocity $\left(\sim 7^{\circ}\right.$ lon/day of phase speed). The geopotential long waves present a meridional tilting with a NW to SE orientation during the two first composite days (Figure 5a and 5b, left column). During the all compose days, the amplitude of the short waves has changed from the $-20 \mathrm{~m}$ in the trough crossing the Andes ( $\sim 40^{\circ} \mathrm{S} ; 65^{\circ} \mathrm{W}$ at D-2) to -50 $\mathrm{m}$ (Figure $3 \mathrm{a}$, left), when this same trough was above the ocean $\left(\sim 35^{\circ} \mathrm{S} ; 44^{\circ} \mathrm{W}\right.$ at D0) (Figure 3c, left).

The temperature field (Figure 3, right column) of the long wave meridional tilt shows an opposite direction relative to the long wave geopotential (NE to SW). Also observed is a fast phase shift between cold and warm phases at high latitudes. In addition, the temperature of the short waves field has an evolution very similar to the $\mathrm{G}_{\mathrm{h}}$ field, but with a phase lag of approximately $5^{\circ}$ at $35^{\circ} \mathrm{S}$.

Figure 4 shows the kinetic energy $\left(\mathrm{K}_{\mathrm{h}}\right)$, the available potential energy $\left(\mathrm{P}_{h}\right)$ fields for short waves and the respective conversion terms $\left(\mathrm{P}_{\mathrm{h}} \mathrm{K}_{\mathrm{h}}, \mathrm{K}_{1} \mathrm{~K}_{\mathrm{h}}\right.$ and $\left.\mathrm{P}_{1} \mathrm{P}_{\mathrm{h}}\right)$ integrated from the surface to $200 \mathrm{hPa}$ for composite day D-2. In this case the observed values of $\mathrm{K}_{\mathrm{h}}$ are above $12 \times 10^{2} \mathrm{KJ} \mathrm{m}^{-2}$ over most of the South Atlantic as well over southern SA. These features are associated with the jet stream acting in that region (Figure 2a, $\mathrm{D}-2)$. Also, the high value of $\mathrm{P}_{\mathrm{h}}$ observed over Argentina results from the presence of a cold trough at $500 \mathrm{hPa}$ (Figure 3a, D-2), and calculated in the $\mathrm{T}_{\mathrm{h}}$ term of the Equation 1.

The baroclinic conversion $\left(\mathrm{P}_{\mathrm{l}} \mathrm{P}_{\mathrm{h}}\right.$ and $\left.\mathrm{P}_{\mathrm{h}} \mathrm{K}_{\mathrm{h}}\right)$ fields above studied in this region on D-1 (Figures $5 \mathrm{~d}$ and $5 \mathrm{e}$ ) are dominated by a strong conversion from $\mathrm{P}_{1}$ to $\mathrm{P}_{\mathrm{h}}$ above the Uruguay, which will be the cause of the though deepening above this country at the next day (Figure 3c, D0). At the same time part of this energy $\left(\mathrm{P}_{h}\right)$ is converted to short wave Kinetic Energy $\left(\mathrm{K}_{\mathrm{h}}\right)$. The $\mathrm{P}_{1} \mathrm{P}_{\mathrm{h}}$ and $\mathrm{P}_{\mathrm{h}} \mathrm{K}_{\mathrm{h}}$ (Figure 5d and 5e) fields show a pattern with three maxima $\left(\sim 50^{\circ} \mathrm{W}, 30^{\circ} \mathrm{W}\right.$ and $\left.\sim 10^{\circ} \mathrm{W}\right)$. Finally, the barotropic conversion term $\left(\mathrm{K}_{1} \mathrm{~K}_{\mathrm{h}}\right)$ presents only a large area 

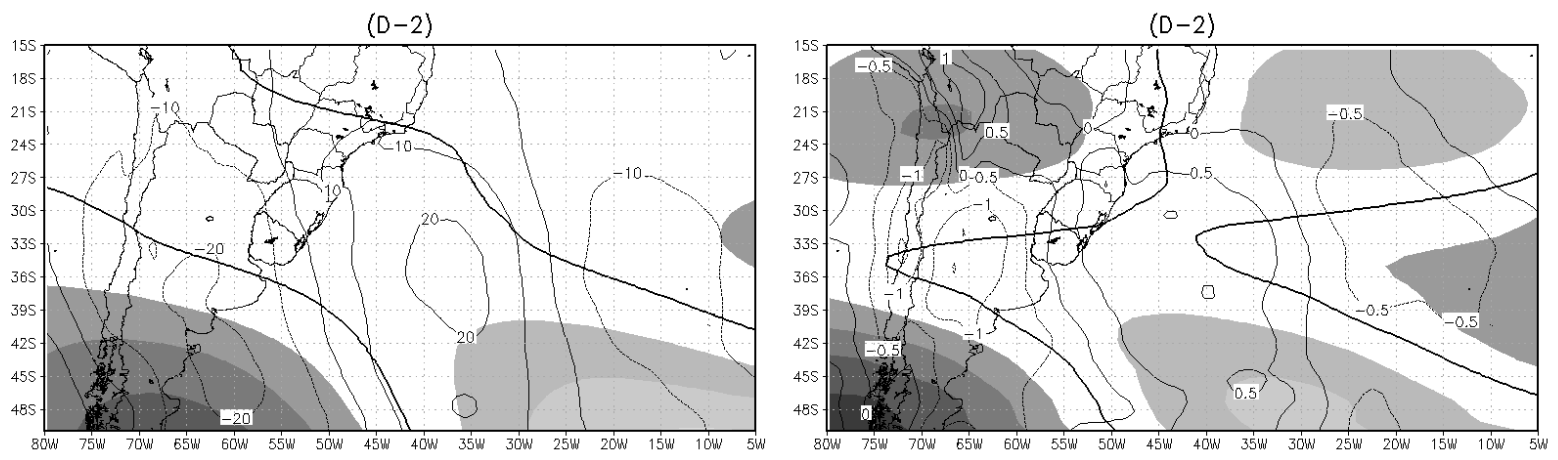

(a)
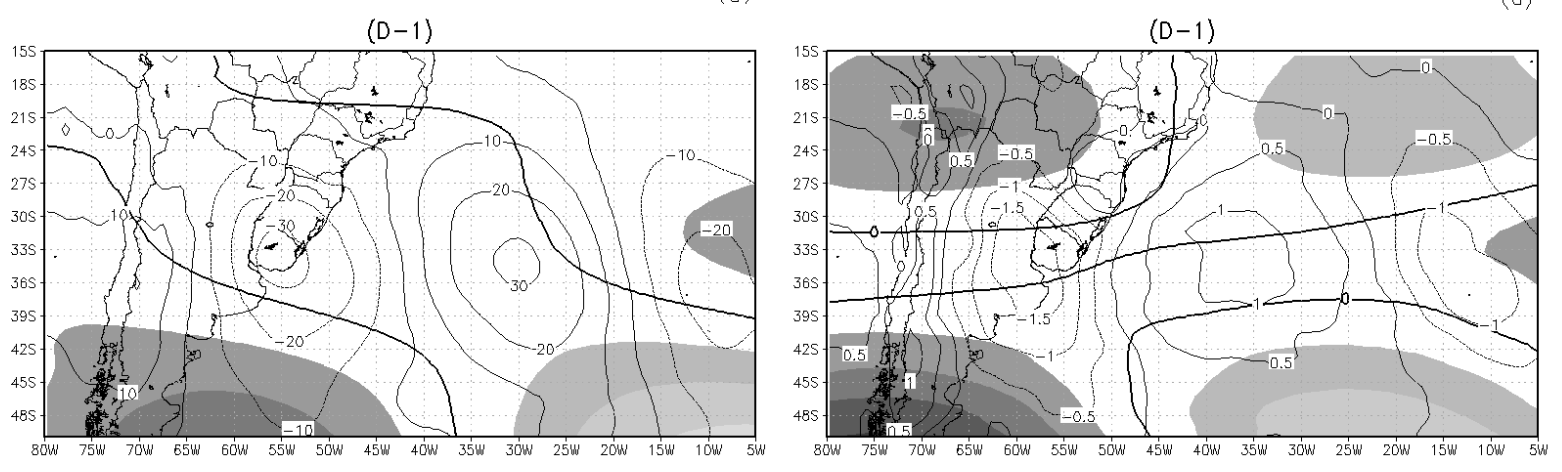

(b)
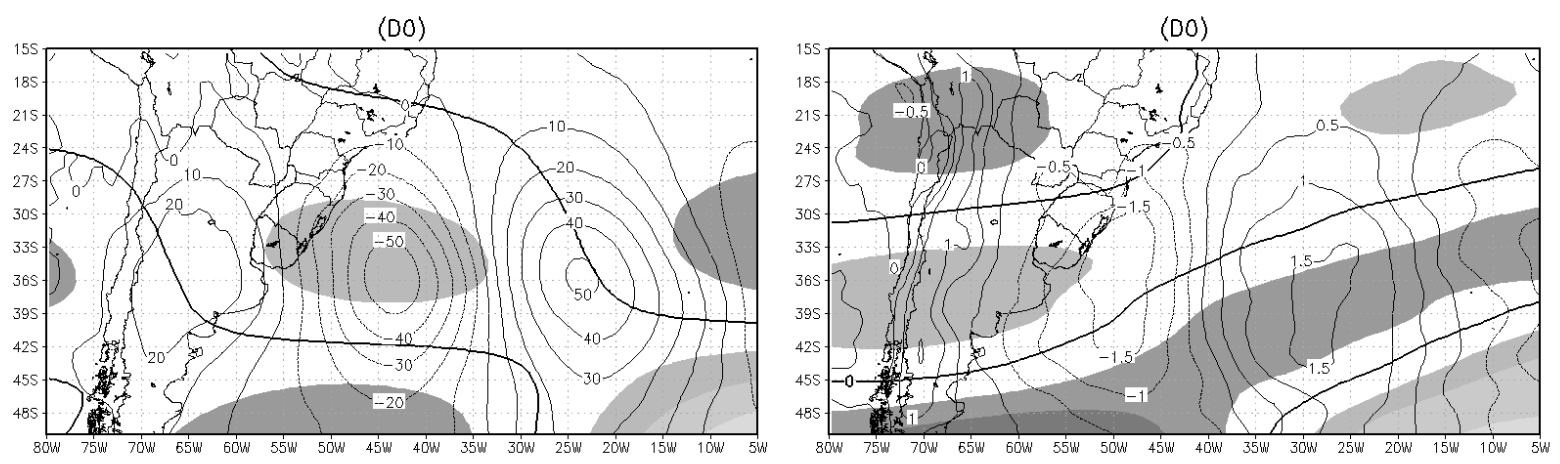

(c)
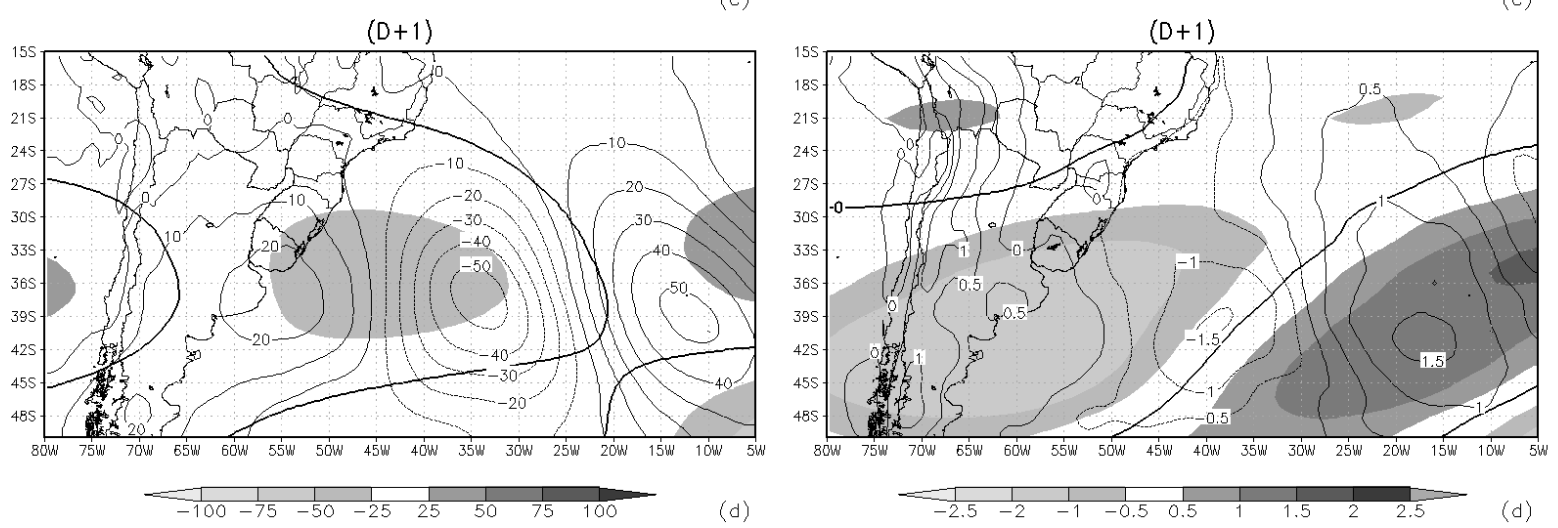

(d)

c)

\section{)}

b) 

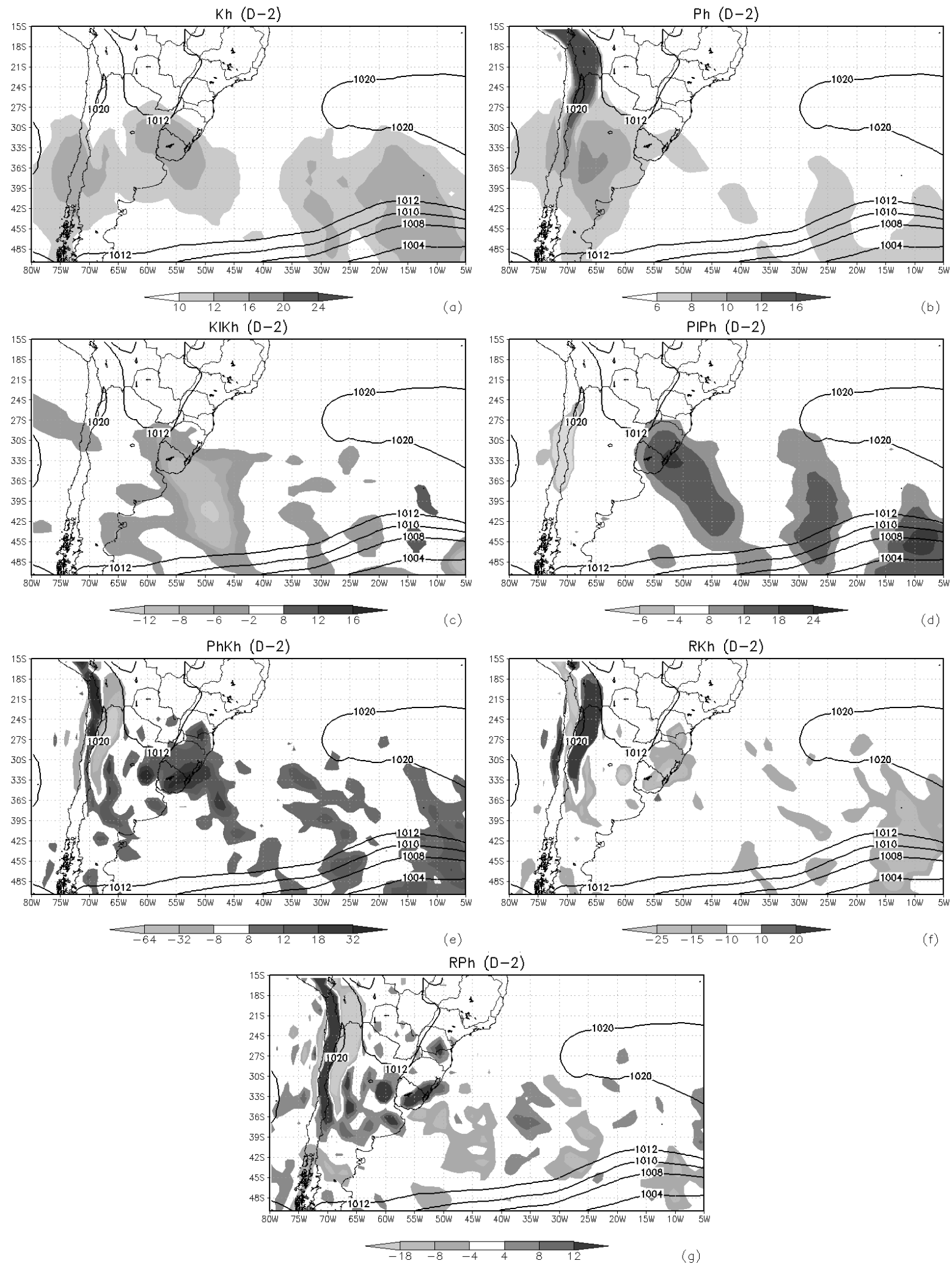

Figure 4 - Kinetic Energy (Kh) and Available Potential Energy ( $\mathrm{Ph}$ ) fields for short waves, their respective conversion terms (PhKh, K1Kh and PIPh) and Residuals ( $\mathrm{RPh}$ and $\mathrm{RKh}$ ) integrated from the surface to $200 \mathrm{hPa}$ on day D-2. (Units: energy fields in $102 \mathrm{KJ}$ m-2 and conversion terms in W m-2). 
with negative values (Figure 5c) above Uruguay, showing that the energy received from $\mathrm{K}_{\mathrm{h}}$ during the baroclinic conversion is converted to Kinetic Energy of the long waves $\left(\mathrm{K}_{1}\right)$, during the cyclogenetic process initiation (Figure 1a, D-1).

As suggested by Gan and Rao (1999) the residuals terms $\mathrm{RK}_{\mathrm{h}}$ and $\mathrm{RP}_{\mathrm{h}}$ represent, to the advection due to the perturbations of high frequency disturbances and the latter the non-conservatives sources and sinks of energy and fluxes of available potential energy also due the high frequency disturbances, respectivaly. When compared to the Lorenz (1955) energetic cycle, $\mathrm{RP}_{\mathrm{h}}$ could be associated to the zonal gradient of temperature generated by diabatic heating due to latent heat release or due to the loss of heat to the space by infrared long wave radiation. The term $\mathrm{RK}_{\mathrm{h}}$ could be related to the loss of kinetic energy due to surface or internal friction.

Dissipation of kinetic energy by eddies $\left(\mathrm{RK}_{\mathrm{h}}\right)$ (Figure 5f) maybe due to internal friction generating loss of energy, especially inside a baroclinic area where there is a strong horizontal wind shear or associated to surface roughness dissipation. The dissipation due to friction shows low values (below $-10 \mathrm{~W} \mathrm{~m}^{-2}$ ) above an area where ciclogenesis takes place. On the other hand, the residual term due to the source/ sink of non conservatives energy and/or flux of the available potential energy $\left(\mathrm{RP}_{\mathrm{h}}\right)$ (Figure $5 \mathrm{~g}$ ) shows three source (i.e. with positives values): one above the Uruguay and southern Brazil, other on the west side of the Andes Cordillera and the last one over Argentina. The first one could be related to latent heating or/and radiation process. The second possibly is due to a noise artificially created by the topography. The third is related to the subsidence of dry air associated to the horizontal gradients of temperature in a limited region (Asnani, 1993 apud Pinto, 2010). In this sense the observed high values of this variable over Uruguay and southern Brazil could be related to a strong zonal gradient of temperature and the release of latent heat associated with convective activity, frequently observed in this region (Rosa, 2006).

On the following day (Figure 5, D-1), an intensification of the magnitude of the $\mathrm{K}_{h}$ and $\mathrm{P}_{1} \mathrm{P}_{h}$ and $\mathrm{P}_{\mathrm{h}} \mathrm{K}_{\mathrm{h}}$ components are observed just after the surface low pressure genesis. The energy converted by $\mathrm{P}_{\mathrm{h}} \mathrm{K}_{\mathrm{h}}$ increases the $\mathrm{K}_{\mathrm{h}}$ over the surface cyclone and over the south-eastern Brazilian coast. One can observe that the conversion of the $\mathrm{P}_{1} \mathrm{P}_{h}$ (Figure $5 \mathrm{~d}$ ) term deepens the short wave scale cyclone (Figure 3b, D-1). As a consequence, an increase of the conversion between $\mathrm{P}_{h}$ and $\mathrm{K}_{h}\left(\mathrm{P}_{\mathrm{h}} \mathrm{K}_{\mathrm{h}}\right)$ is observed (Figure $5 \mathrm{e})$, resulting in an increase of the relative vorticity of the low pressure system, which transfers part of this energy to the long wave modes by $\mathrm{K}_{1} \mathrm{~K}_{\mathrm{h}}$ (Figure $5 \mathrm{c}$ ).

A large area stands out over Argentina where a strong baroclinic conversion $\left(\mathrm{P}_{1} \mathrm{P}_{\mathrm{h}}\right.$ and $\left.\mathrm{P}_{\mathrm{h}} \mathrm{K}_{\mathrm{h}}\right)$ is taking place, especially at the middle and low tropospheric levels (not shown). The magnitude of the $\mathrm{P}_{\mathrm{h}} \mathrm{K}_{\mathrm{h}}$ is a function of the short waves temperature (Equation 7). It amplifies when the temperature of the long and short waves shift to a negative phase associated with a strong subsidence (not shown) to the west of the surface cyclone. The conversion term $\left(\mathrm{P}_{\mathrm{h}} \mathrm{K}_{\mathrm{h}}\right)$ grows relatively fast (Figure 5e) considering the ciclogenetic activity in this composite day especially in the western sector or above the surface vortex (Figure 3b, D-1), anticipating the pattern observed on the next day. On the other hand, the growing of the $\mathrm{P}_{1} \mathrm{P}_{h}$ is associated with a strong southerly cold air transport indicated by the second term to the right of Equation 5 on the west side of the low. On the south side of this low, the growing of the $\mathrm{P}_{1} \mathrm{P}_{\mathrm{h}}$ is due the warm advection.

The synoptic analysis of the composed field shows a short wave ridge crossing the Andes mountain range at $500 \mathrm{hPa}$ (Figure 3b, D-1, left), simultaneously with the displacement of a small cold ridge at $500 \mathrm{hPa}$, between $30^{\circ}$ and $48^{\circ} \mathrm{S}$ above the Andes (Figure 3b, D-1, right). Also, the temperature field (Figure 3b, D-1, right) shows a positive anomaly at $500 \mathrm{hPa}$ due to subsidence probably forced by this mountain range (dry adiabatic process). The barotropic term $\left(\mathrm{K}_{1} \mathrm{~K}_{\mathrm{h}}\right)$ indicates that the surface short wave cyclone near the east coast of southern Brazil is transferring kinetic energy to the long wave mode, intensifying the long wave zonal and the meridional wind (Equation 6).

The residual term of kinetic energy $\left(\mathrm{RK}_{\mathrm{h}}\right)$ is strongly negative either downstream or upstream of the cyclone position. This feature results from cold air advection above this area, probably associated with the strong horizontal wind shear and surface roughness, which contribute to the dissipation of short wave cyclonic energy. Also, the residual diabatic term $\left(\mathrm{RP}_{\mathrm{h}}\right.$, Figure $5 \mathrm{~g}$ ) has a considerable magnitude only around the surface cyclone. This term is associated with the convective activity that occurs around this synoptic system, but it is not the principal factor for the increase of the cyclone's intensity. Another area with strong $\mathrm{RP}_{\mathrm{h}}$ is also noticeable in the western sector of the same cyclone above Uruguay, south of Brazil and northwestern Argentina, and it could be related to an enhanced meridional gradient of the short wave temperature (Figure 3b, D-1, right).

In the D0 composite (Figure 6) one can observe that the absolute magnitude of all terms increases during the energy cycle. The pressure in the cyclone center drops to values below $1000 \mathrm{hPa}$ (Figure 1c, D0) and the kinetic energy $\left(\mathrm{K}_{\mathrm{h}}\right)$ reaches values around $2 \times 10^{3} \mathrm{KJ} \mathrm{m}^{-2}$ in the center of the cyclone (Figure 6a). This increase is explained by the large magnitude of the wind components as suggested by Equation 2. The magnitude of $\mathrm{P}_{\mathrm{h}}$ also increases following the negative phase of the short wave temperature and geopotential (Figure 3c, D0), the latter of which is balanced only by high static stability of cold air which is observed in the cyclone's western sector. 

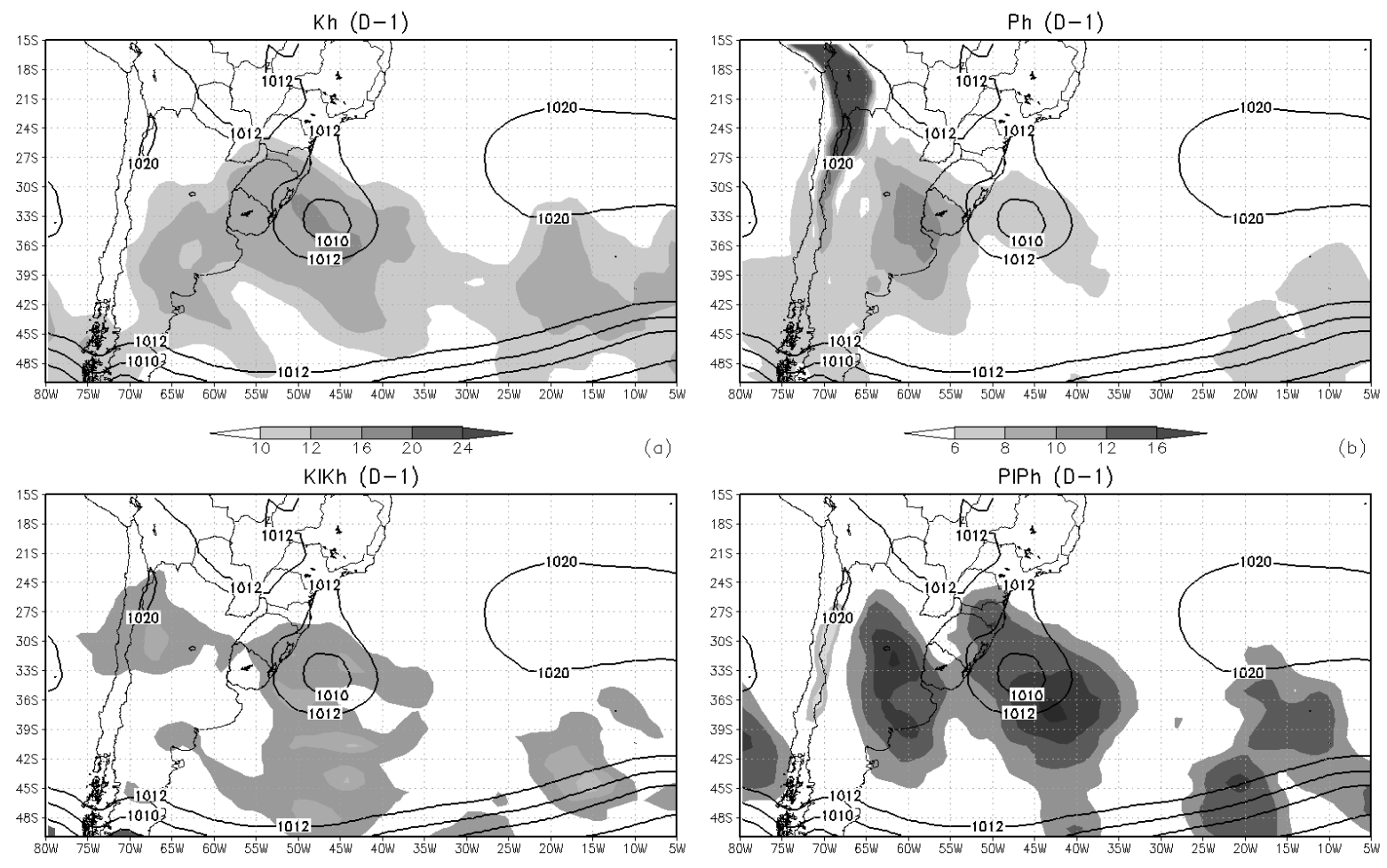

(b)
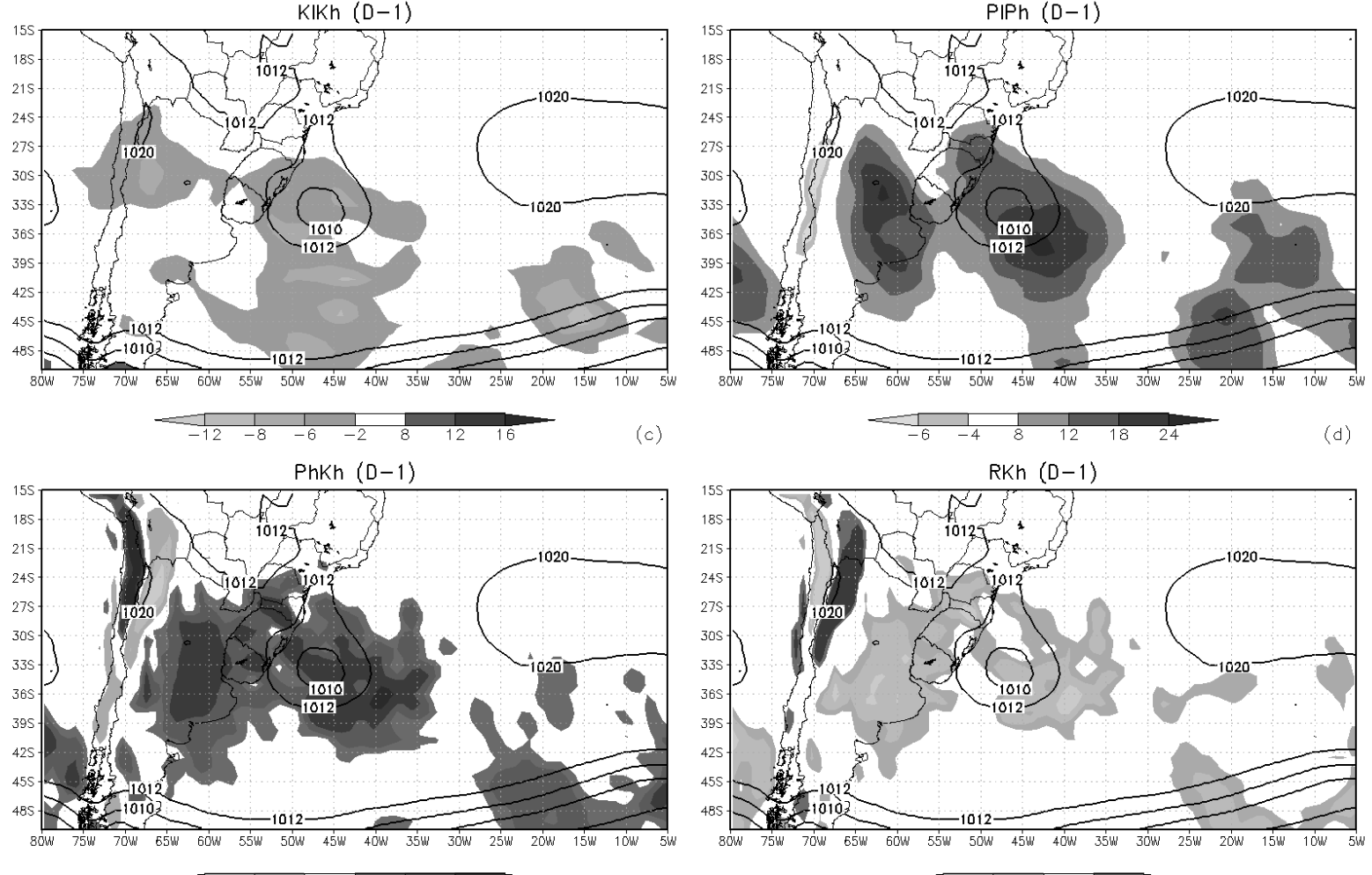

\section{c)}

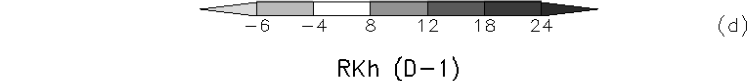

(d)
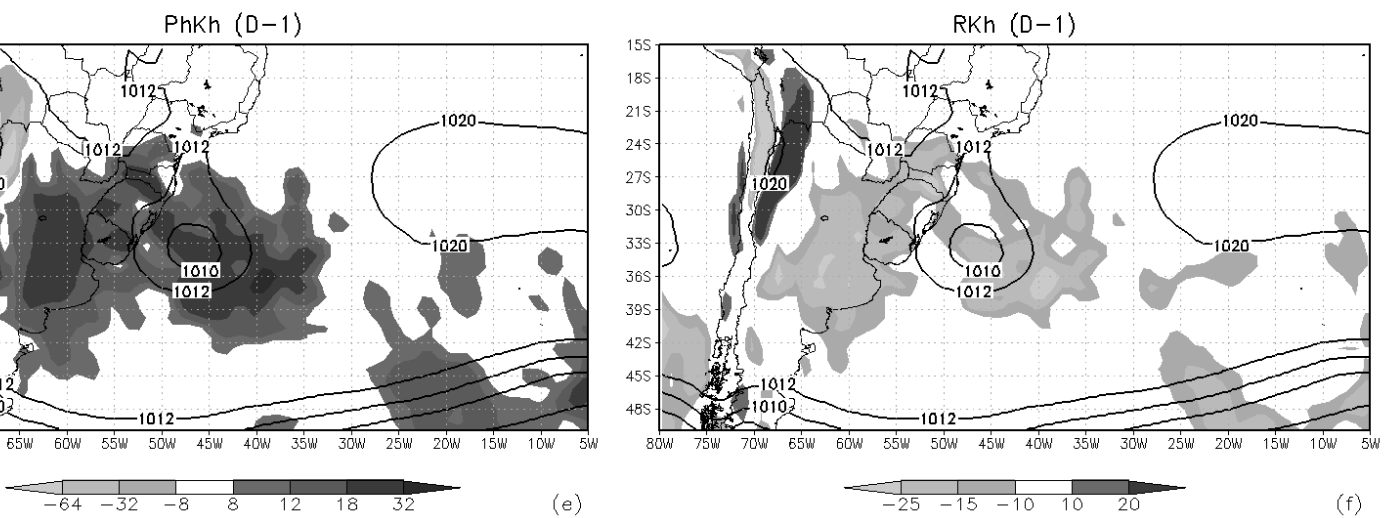

$\mathrm{RPh}(\mathrm{D}-1)$
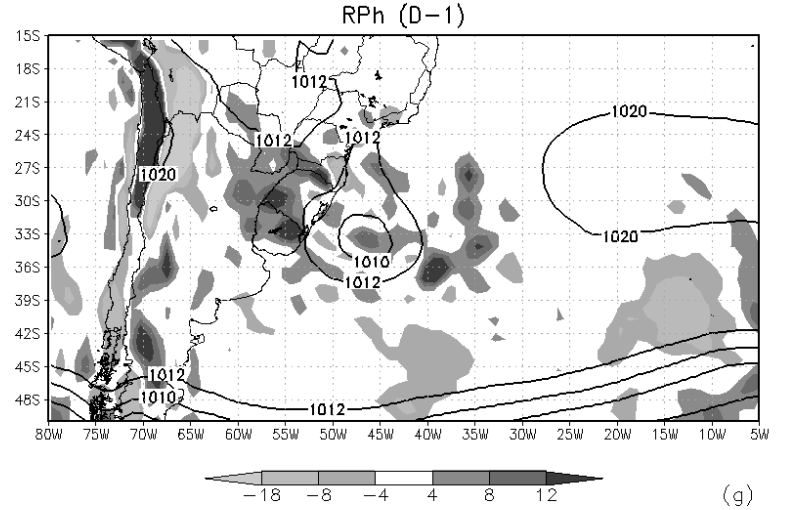

$(g)$

Figure 5 - Similar to Figure 4 but for day D-1. 

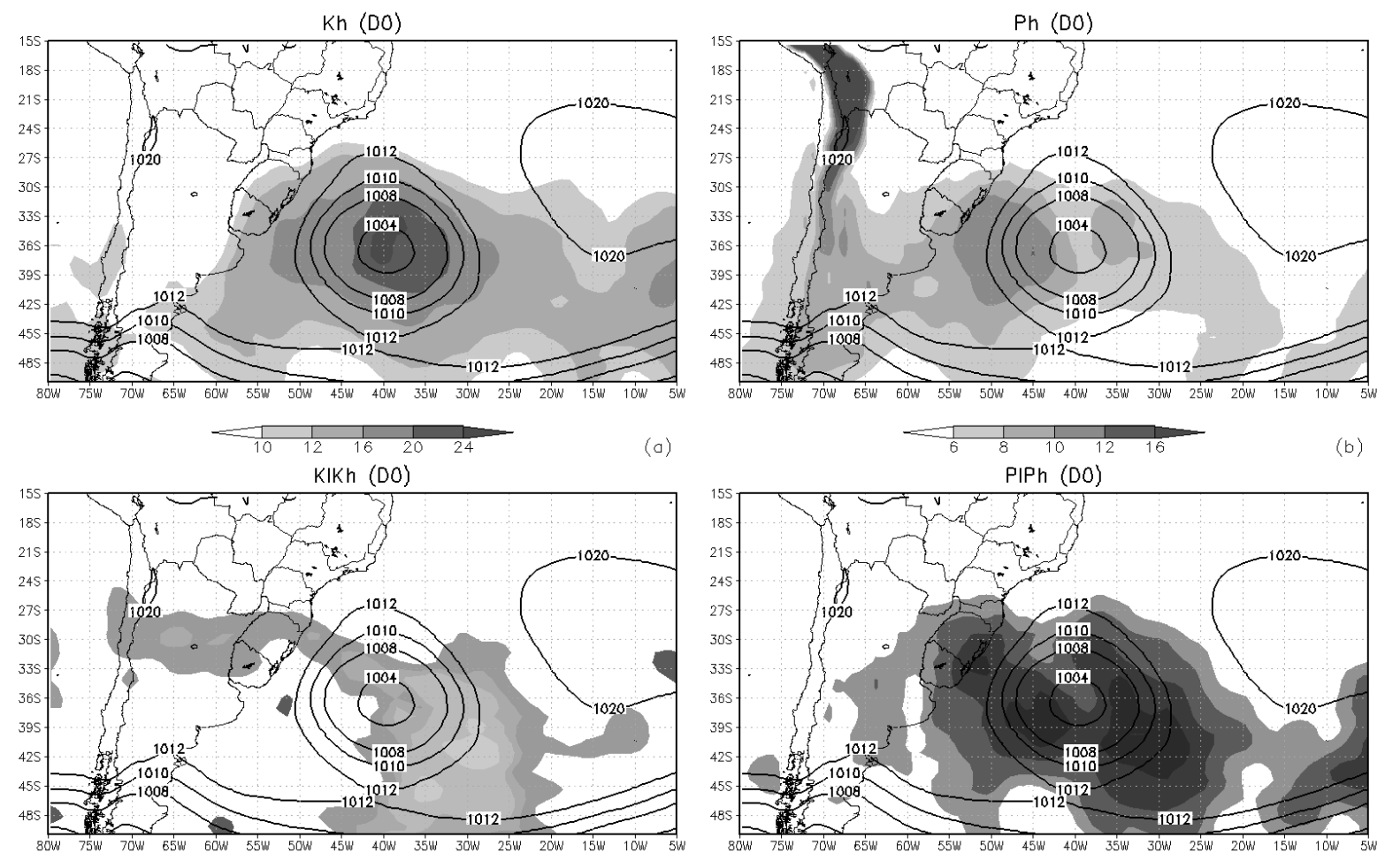

(b)

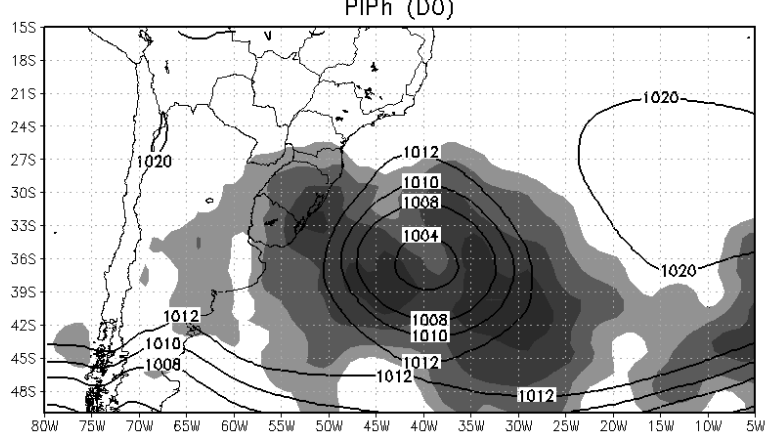

(c)
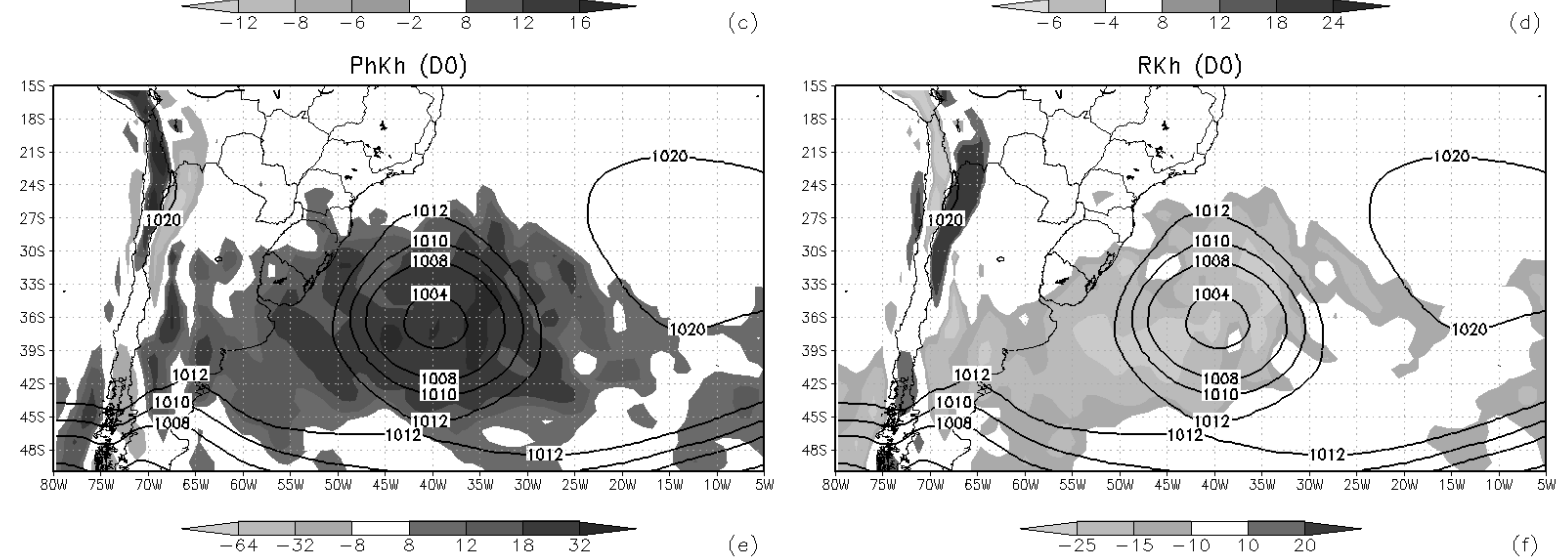

(e)
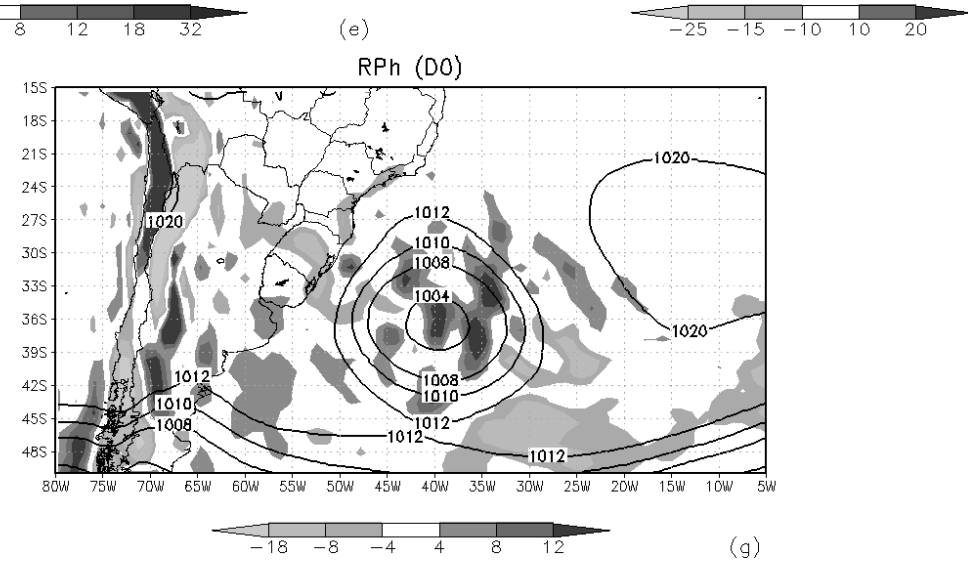

Figure 6 - Similar to Figure 4 but for day D0. 
The most relevant aspect observed on D0 is the displacement of the strong barotropic conversion region to the eastern sector of the low surface pressure. Previously, this same sector was inside and at the southern sector of the low pressure system (Figures $4 \mathrm{~d}, 5 \mathrm{e}, 5 \mathrm{~d}$ and $5 \mathrm{e}$ ). This displacement is associated with the jet stream above, whose core is at $45^{\circ} \mathrm{S}$ and $20^{\circ} \mathrm{W}$, contributing with advection of zonal momentum (first term of right hand side of the Equation 6).

On D0, an intensification of the conversion of the available potential energy form long $\left(\mathrm{P}_{1}\right)$ to short $\left(\mathrm{P}_{h}\right)$ waves is observed (Figure 6d). At the same time $\mathrm{P}_{\mathrm{h}}$ is transferred to the short wave kinetic energy $\left(\mathrm{K}_{\mathrm{h}}\right)$ (up to $18 \mathrm{~W} \mathrm{~m}^{-2}$ near the center of the surface low) (Figure 6e). This increase of the baroclinic activity is also evident where the geopotential and the temperature of the short wave are $90^{\circ}$ degrees out of phase (Figure 3c, D0).

The absolute magnitude of the dissipative term $\left(\mathrm{RK}_{\mathrm{h}}\right)$ increases in the western sector of the cyclone (Figure 6f), possibly due to the cold advection in this sector (Figure 1c, D0), where there is an expressive wind shear associated to the jet stream above (Figure 2c, D0). Also, the $\mathrm{RP}_{\mathrm{h}}$ term still contributes positively in the central areas of the surface low (Figure $6 \mathrm{~g}$ ), but shows significant negative values above southern Brazil, due to a cold high pressure ridge above this region, where is occurring a radiative long wave loss into space.

On the last day studied (D+1, Figure 7), the surface cyclone begins to merge in the westerly wind circulation. However, the magnitude of all terms, including the residual ones, has not changed considerably compared to the last day. Looking at the surface pressure field it is possible to observe a weakening of low surface pressure; meanwhile the maximum of the energetic terms displace to the east relative to the center of the low. A small increase of the maximum magnitude and organization of the diabatic term $\left(\mathrm{RP}_{\mathrm{h}}\right)$ to the north of the low is also observed (Figure $7 \mathrm{~g}$ ), possibly associated with a cold front located on this sector.

In the composite $\mathrm{D}+2$ (not shown) the surface cyclone merged with the flow, with the atmospheric circulation showing a similar pattern compared to that observed on D-2 (Figure 4).

In Table 1 a higher frequency of cyclogenesis during the austral autumn is observed, followed by the spring and winter. In this last season there is a peak of cyclogenesis above SA similar to what was found by Gan and Rao (1991). With the objective of characterizing the seasonal variability from this point on, we focused only on the austral spring and autumn seasons, since the frequency of cyclonegesis is relatively low during the austral summer season. During the austral autumn (April, May and June) and spring (October, November and December) seasons ofcd $\mathrm{f}$ the $2003-2011$ period, 20 and 16 cyclogenesis events were observed, respectively.
In the autumn months during the two days prior to maximum cyclogenesis, the jet stream had appreciable wind speed with magnitudes above $40 \mathrm{~m} / \mathrm{s}$, centered at $30^{\circ} \mathrm{S}$ and $50^{\circ} \mathrm{W}$. The jet stream also had a cyclonic curvature with a trough centered at $55^{\circ} \mathrm{W}$. During the austral spring the jet stream acquired less cyclonic curvature due to the prevailing upper levels circulation that drives the jet stream to an anticyclonic curvature (Figure 8a, D0, left). On day D-1 there were two jet stream branches, one over southern Brazil and the other one at $40^{\circ} \mathrm{S}$ and $25^{\circ} \mathrm{W}$. On D0 the observed atmospheric flow was similar to the one observed two days before. The first jet stream with a meridional structure was associated with barotropic conversion $\left(\mathrm{K}_{1} \mathrm{~K}_{\mathrm{h}}\right)$ and partially with a baroclinic $\left(\mathrm{P}_{\mathrm{h}} \mathrm{K}_{\mathrm{h}}\right)$ conversion (Figures $8 \mathrm{a}, 8 \mathrm{c}$ and $8 \mathrm{~d}$ ), and the latter was probably also receiving energy from downstream advection. During the austral autumn, the short wave mode geopotential $\left(\mathrm{G}_{\mathrm{h}}\right)$ showed an absolute magnitude higher than those observed during the austral spring (Figure 8b). This feature was already observed by Rao et al. (2002) in situations when the energy apparently is concentrated at long wave modes.

Finally, during the austral autumn an increase in the magnitude of the energy conversion of all terms of the energetic cycle is observed (Figure 8c-8e, left). This is related to an increase of the intensity of the surface cyclone and a great availability of kinetic energy and available potential eddy energy.

\section{CONCLUNDING REMARKS}

An analysis of four composite days, using 58 cyclogenetics cases over the southern coast of Brazil shows that the genesis of these cyclones is associated with baroclinic conversion processes $\left(\mathrm{P}_{\mathrm{l}} \mathrm{P}_{\mathrm{h}}\right.$ to $\left.\mathrm{P}_{\mathrm{h}} \mathrm{K}_{\mathrm{h}}\right)$. In addition, the barotropic term $\left(\mathrm{K}_{1} \mathrm{~K}_{\mathrm{h}}\right)$ extracts kinetic energy from the short wave $\left(\mathrm{K}_{\mathrm{h}}\right)$ and converts it to the long waves $\left(\mathrm{K}_{1}\right)$. As soon as the surface lows grow, the area and magnitude of the conversion increase at the same rate.

On day D-1 the most important conversion term was the baroclinic one $\left(\mathrm{P}_{1} \mathrm{P}_{h}\right)$, acting as an energy source for the short wave mode $\left(\mathrm{P}_{\mathrm{h}}\right)$ due to warm air advection on SE side of the low system and due to cold advection on $\mathrm{W}$ side of the same low. This term, is followed by the barotropic one $\left(\mathrm{K}_{1} \mathrm{~K}_{\mathrm{h}}\right)$, which increased the kinetic energy of the long wave mode $\left(\mathrm{K}_{1}\right)$. This conversion is associated with the deepening of geopotential long wave modes $\left(\mathrm{G}_{1}\right)$, as already observed in previous studies (Reboita, 2006, Lenters and Cook, 1997, Satyamurty et al., 1980). As soon as the $\mathrm{G}_{\mathrm{h}}$ term is in phase with $\mathrm{G}_{1}$ on $\mathrm{D}-1$, the $\mathrm{P}_{\mathrm{h}} \mathrm{K}_{\mathrm{h}}$ term increases in magnitude, becoming the dominant one. The following $\mathrm{P}_{1} \mathrm{P}_{\mathrm{h}}$ term also makes a significant contribution.

On the following days it was possible to observe an increase of the magnitude of the conversion terms, with a clear 

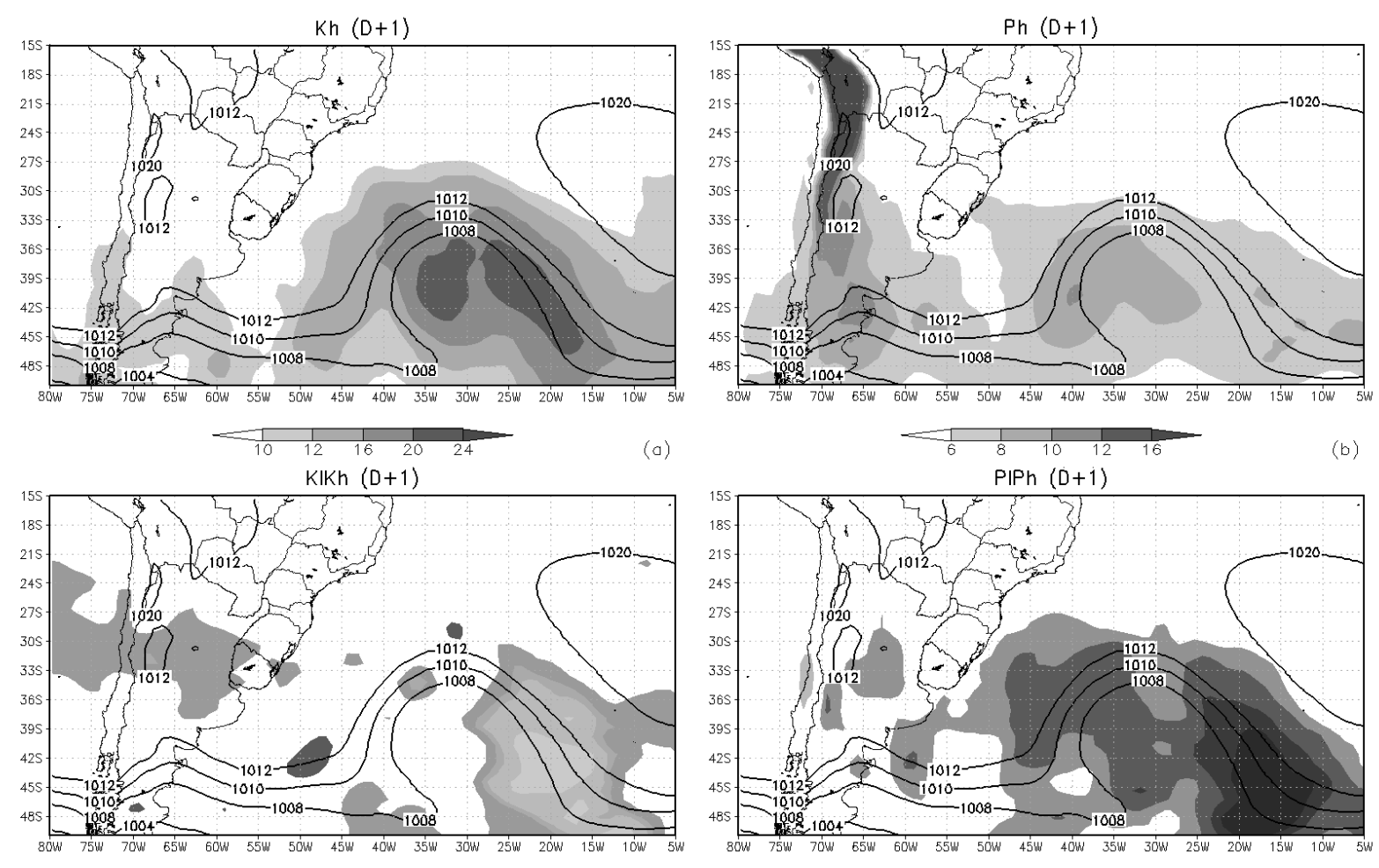

(b)
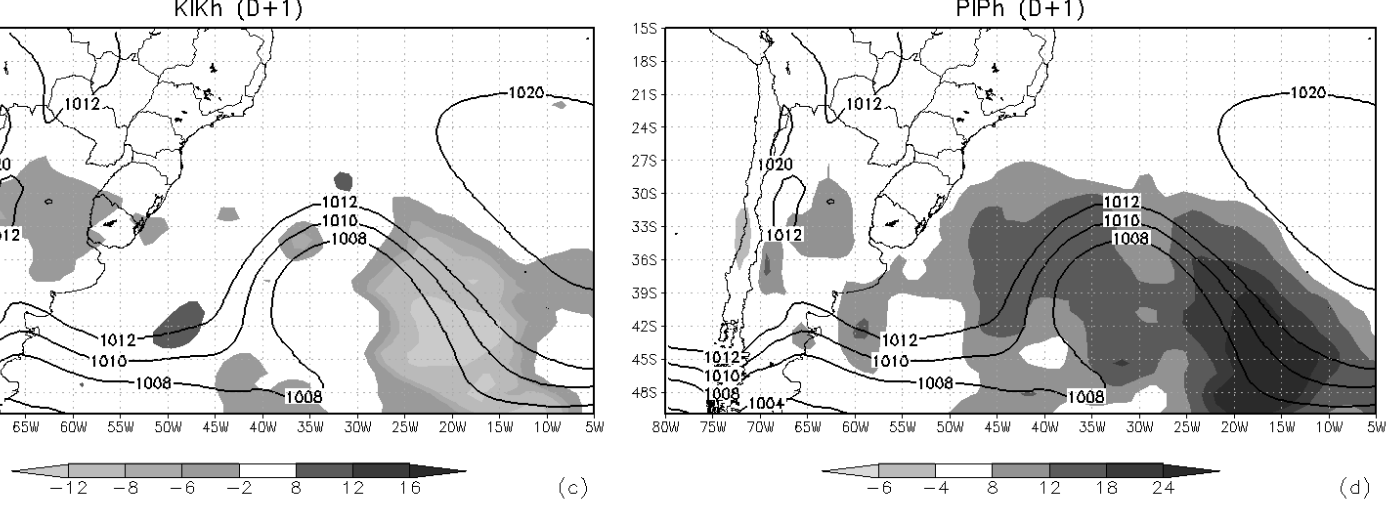

(c)
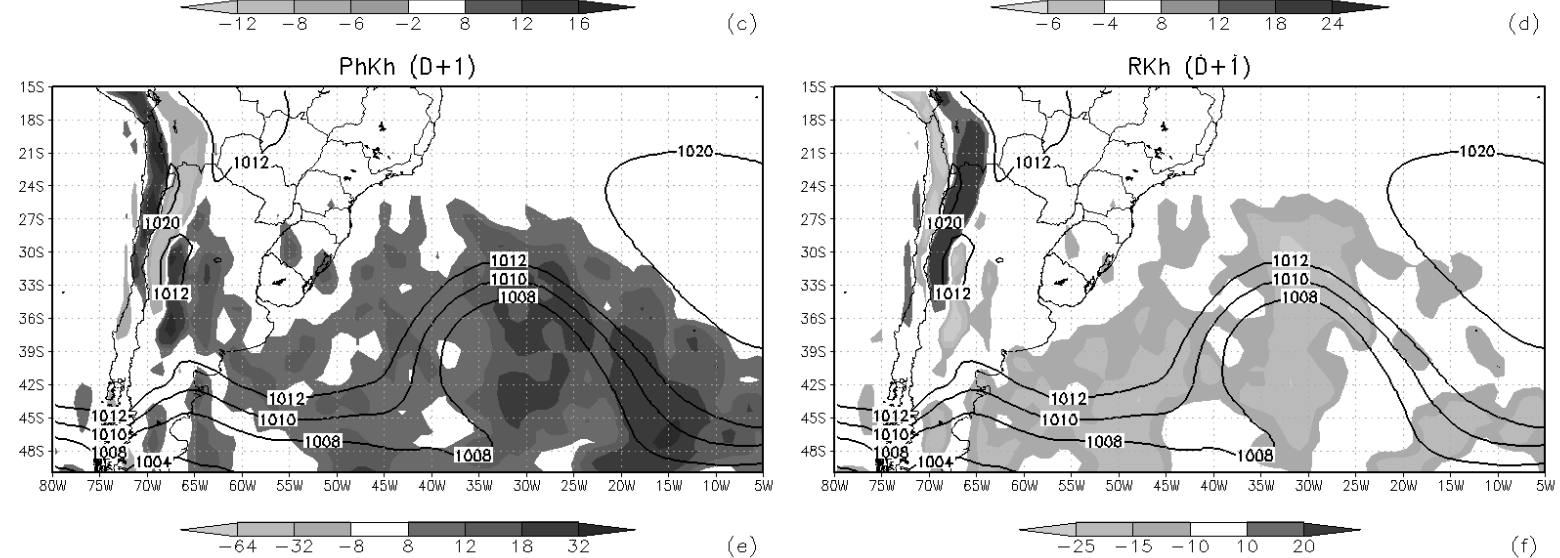

(e)

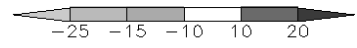

$\mathrm{RPh}(\mathrm{D}+1)$

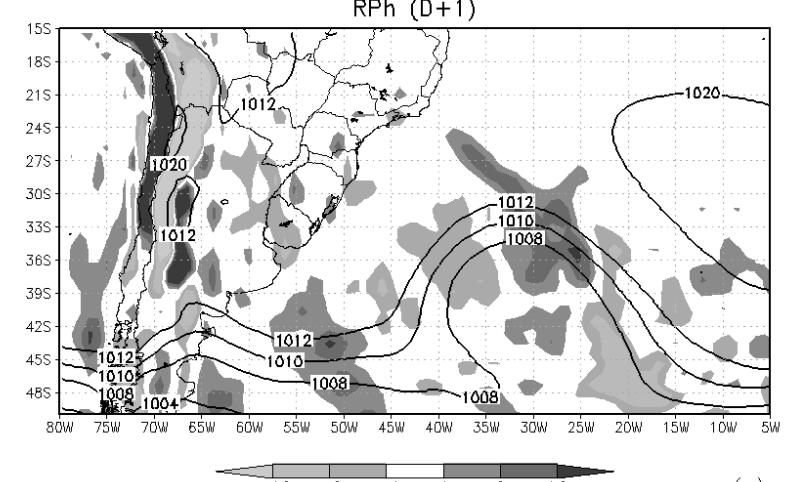

(g)

Figure 7 - Similar to Figure 4 but for day D+1. 

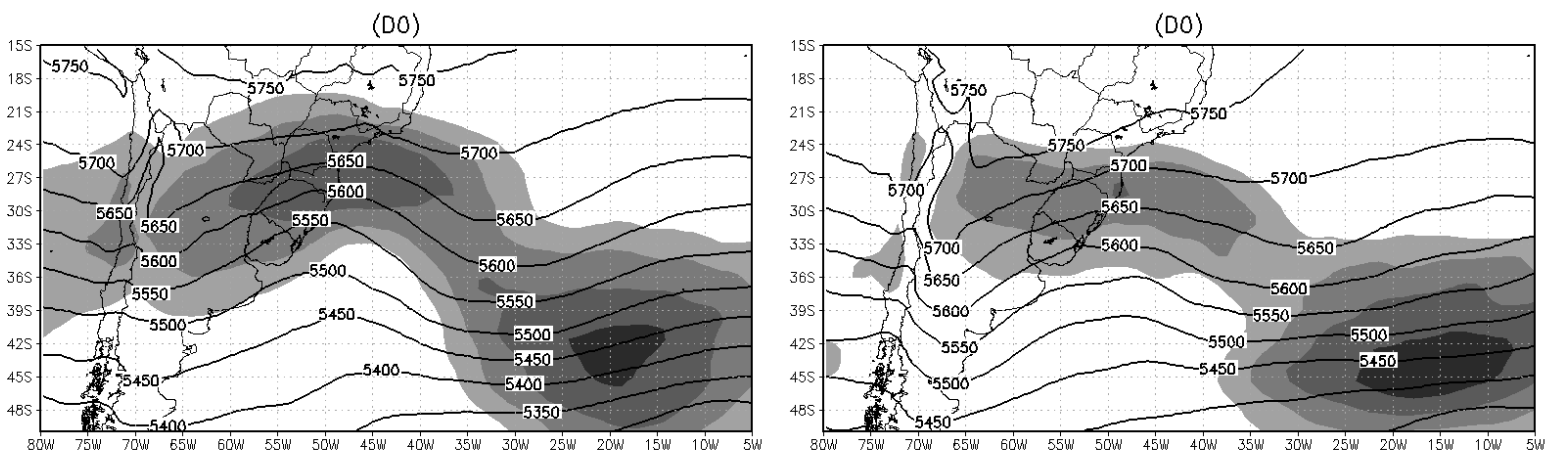

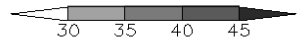

(DO)
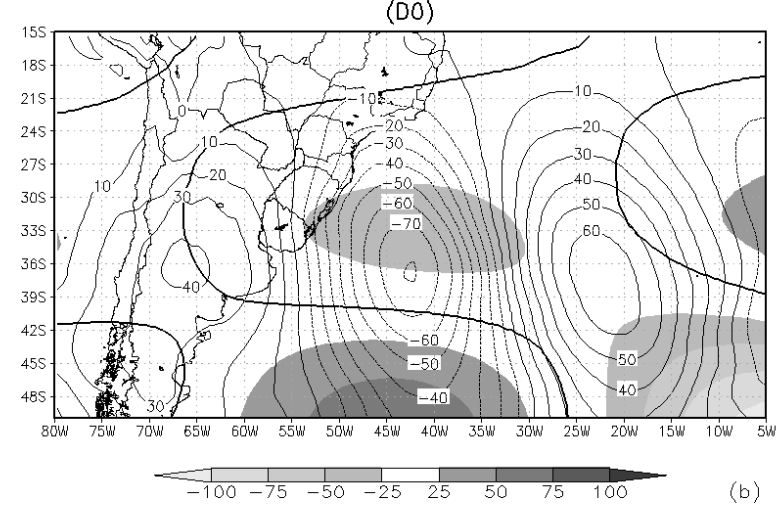

(b)
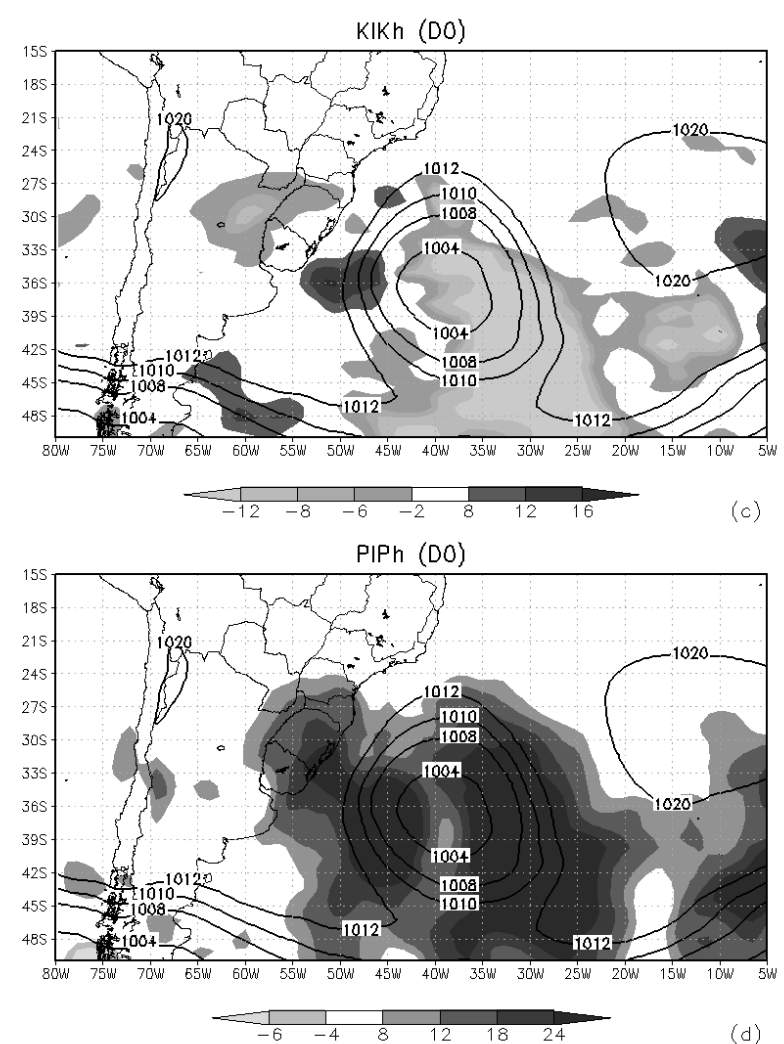

(a)

(c)

(d)
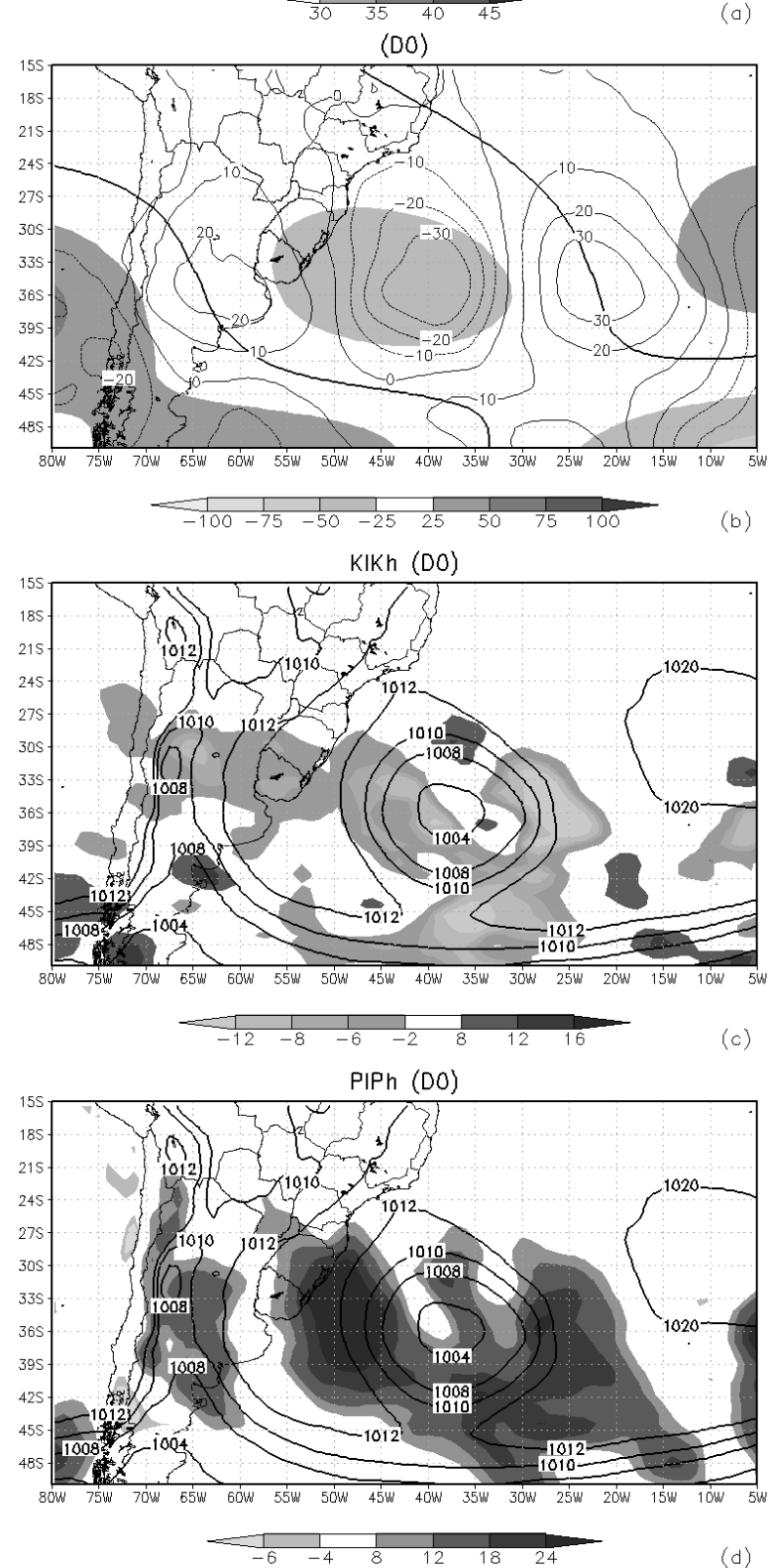

(b) . 

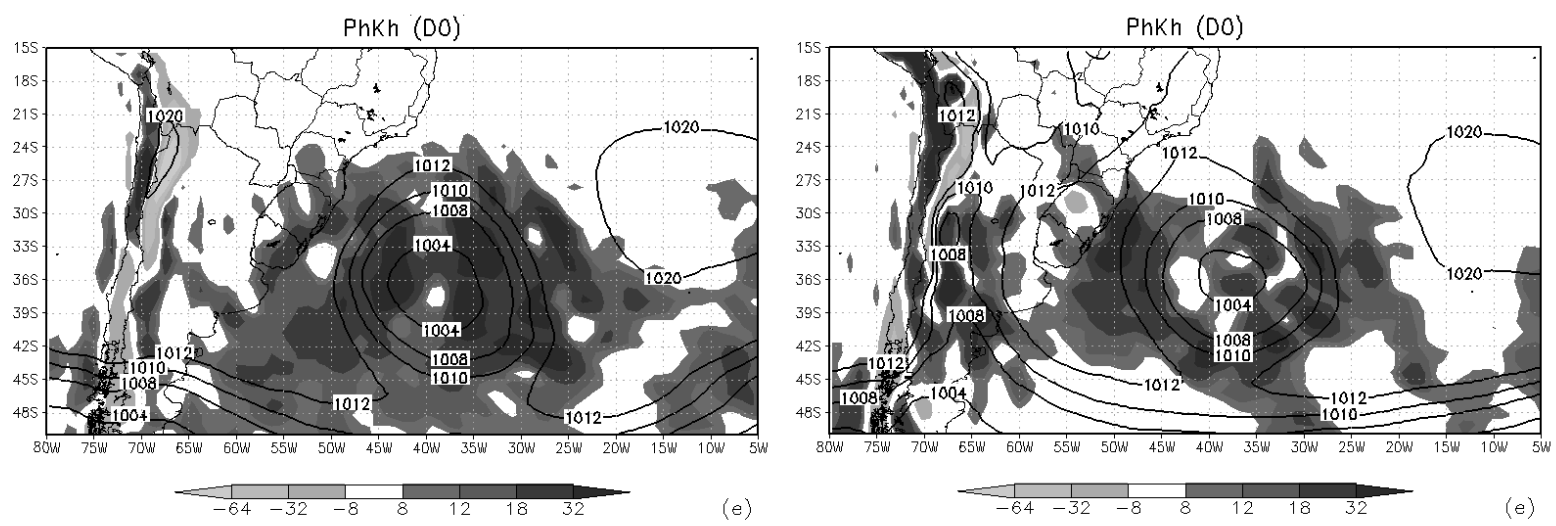

Figure 8 - Comclusion,

transference of kinetic energy $\left(\mathrm{K}_{1} \mathrm{~K}_{\mathrm{h}}\right)$ from short wave modes to the long wave modes located downstream of the low surface pressure. This transfer of energy may increase the jet stream strength downstream of the low surface pressure which also could be receiving energy from convergence of the ageostrophic flow. The internal dissipation term $\left(\mathrm{RK}_{\mathrm{h}}\right)$ was not important compared to the conversion terms, except in the area observed in the SW sector of the surface low after D-1. The source/sink of non conservative energy and flux of the available potential energy $\left(\mathrm{RP}_{\mathrm{h}}\right)$ at any phase of the system development did not contributed to the deepening of the surface low, showing that is due only by baroclinic conversion processes and not depend of the convective activity inside it.

Typically, the observed cyclogenesis which takes place during the austral spring and autumn seasons does not show significant differences, except for an increase of the available kinetic energy, eddy potential energy and baroclinic, and in the barotropic conversion terms during the austral autumn. Both seasons showed a similar distribution frequency, similar to that observed by Gan and Rao (1991).

\section{BIBLIOGRAPHY}

FERREIRA, C. C. Ciclogêneses e ciclones extratropicais na Região Sul-Sudeste e suas influências no Tempo. Dissertação de Mestrado em Meteorologia, Instituto Nacional de Pesquisas Espaciais, 93p, 1988.

GAN, M. A; RAO, V. B. Surface cyclogenesis over South America. Monthly Weather Review, v. 119, p.1293-1302, 1991.

GAN, M. A; RAO, V. B. The influence of the Andes cordillera on transient disturbances. Monthly Weather Review, v. 122, n. 6, p.1141-1157, 1994.

GAN, M. A; RAO, V. B. Energetics of the high frequency disturbances over South America. Revista Brasileira de Geofísica, v. 17, n. 1, p. 21-28, 1999.
HOSKINS, B. J; HODGES, K. I. A new perspective on Southern Hemisphere Storm Track. Journal of Climate, v. 18, p. 4108-4129, 2005.

KLEIN, W. H. Principal tracks and mean frequencies of cyclones and anticyclones in the Northern Hemispheres. Research Paper No. 40, US Weather Bureau, US Government Printing Office, 60p, 1957.

LAU, N. C.; LAU, K. M. The structure and energetics of midlatitude disturbances accompanying cold-air outbreaks over east Asia. Monthly Weather Review, v. 112, n. 7, p. 1309-1327, 1984.

LENTERS, J. D.; COOK, K. H. On the origin of the Bolivian High and related circulation features of the South American climate. Journal of Atmospheric Sciences, v. 54, p. 656-677, 1997.

LORENZ, E. N. Available potential energy and the maintenance of the general circulation. Tellus, v.7, p.157-167, 1955.

MENDES, D.; SOUZA, E.; TRIGO, I.; MIRANDA, P.. On precursors of South American cyclogenesis. Tellus, v. 59, p.114-121, 2007.

NIELSEN, J. W.; DOLE, R. M. A survey of extratopical cyclone characteristics during GALE. Monthly Weather Review, v. 120, n. 7, p. 1156-1167, 1992.

PETTERSSEN, S. Weather analysis and forecasting. Volume I, Second Edition, New York: McGraw Hill Book Co. Inc., $428 \mathrm{p}, 1956$.

PINTO, J. R. D. Estudo da estrutura e energética dos distúrbios de escala sinótica na costa leste da América do Sul. Dissertação de Mestrado, Instituto de Astronomia, Geofísica e Ciências Atmosféricas IAGUSP, 90p, 2010.

PIVA, E. D.; GAN, M. A.; RAO, V. B. Energetics of winter troughs entering South America. Monthly Weather Review, v. 138, p. 1084-1103, 2010.

RAO, V. B.; DO CARMO, A. M. C.; FRANCHITO, S. H. Seasonal variations in the southern storm tracks and associated wave propagation. Journal of Atmospheric Sciences, v. 59, p. 1029-1040, 2002. 
REBOITA, M. S. Ciclones extratropicais sobre o Atlântico Sul: Simulação climática e experimentos de sensibilidade. Tese de Doutorado em Meteorologia, Instituto de Astronomia, Geofísica e Ciências Atmosféricas IAGUSP, 359p, 2006.

ROSA, M. B. Estimativa dos perfis de liberação de calor latente das regiões tropicais a partir de dados do radar TRMM. Tese de Doutorado em Meteorologia, Instituto de Astronomia, Geofísica e Ciências Atmosféricas IAGUSP, 203p, 2006.

ROEBBER, P. J. Statistical analysis and updated climatology of explosive cyclones. Monthly Weather Review, v. 112, p. 1577-1589, 1984.

SALTZMAN, B.; FLEISHER, A. The modes of release of available potential energy in the atmosphere. Journal of Geophysical Research, v. 65, p. 1215-1222, 1960.

SANDERS, F.; GYAKUM, J. R. Synoptic-dynamic climatology of the bomb. Monthly Weather Review, v. 180, n. 10, p. 1589-1606, 1980.
SATYAMURTY, P.; SANTOS, R. P.; LEMOS, M. A. M. On the stationary trough generated by the Andes. Monthly Weather Review, v. 108, p.510-520, 1980.

SELUCHI, M. E. Diagnóstico y prognóstico de situaciones sinópticas conducentes a ciclogénesis sobre el este de Sudamérica. Geof. International, v. 34, n. 2, p. 171-186, 1995

SELUCHI, M. E; OYAMBURO, N. de C.; ROZANTE, J. R. Análisis de un desarrollo ciclónico en la costa oriental del América del Sur. Revista Brasileira de Meteorologia, v. 16, p. 51-65, 2001.

SINCLAIR, M. R. An objective cyclone climatology for the Southern Hemisphere. Monthly Weather Review, v. 122, n. 10, p. 2239-2256, 1994.

SINCLAIR, M. R. A climatology of cyclogenesis for the Southern Hemisphere. Monthly Weather Review, v. 123, n. 6, p. 1601-1619, 1995. 